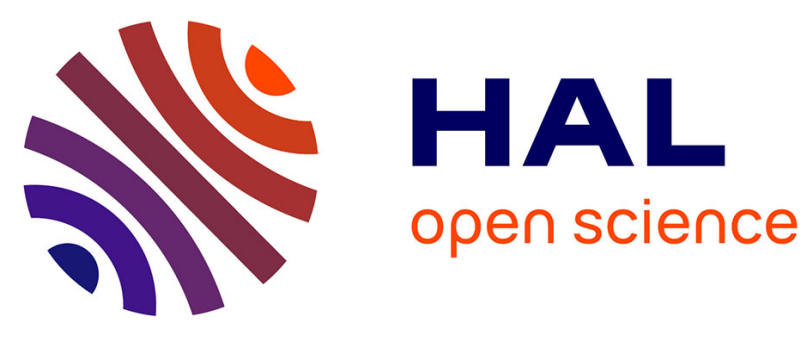

\title{
Formation of single domain magnetite by green rust oxidation promoted by microbial anaerobic nitrate-dependent iron oxidation
}

Jennyfer Miot, Jinhua Li, Karim Benzerara, Moulay Tahar Sougrati, Georges Ona-Nguema, Serge Bernard, Jean-Claude Jumas, François Guyot

\section{To cite this version:}

Jennyfer Miot, Jinhua Li, Karim Benzerara, Moulay Tahar Sougrati, Georges Ona-Nguema, et al. Formation of single domain magnetite by green rust oxidation promoted by microbial anaerobic nitrate-dependent iron oxidation. Geochimica et Cosmochimica Acta, 2014, 139, pp.327-343. 10.1016/j.gca.2014.04.047 . hal-01016121

\section{HAL Id: hal-01016121 \\ https://hal.science/hal-01016121}

Submitted on 25 Apr 2016

HAL is a multi-disciplinary open access archive for the deposit and dissemination of scientific research documents, whether they are published or not. The documents may come from teaching and research institutions in France or abroad, or from public or private research centers.
L'archive ouverte pluridisciplinaire HAL, est destinée au dépôt et à la diffusion de documents scientifiques de niveau recherche, publiés ou non, émanant des établissements d'enseignement et de recherche français ou étrangers, des laboratoires publics ou privés. 
1 Formation of single domain magnetite by green rust oxidation promoted by microbial

2

3

4 Jennyfer Miot ${ }^{1,2, *}$, Jinhua $\mathrm{Li}^{2}$, Karim Benzerara ${ }^{2}$, Moulay Tahar Sougrati ${ }^{3,4}$, Georges Ona-

5 Nguema $^{2}$, Sylvain Bernard ${ }^{2}$, Jean-Claude Jumas ${ }^{3,4}$, François Guyot ${ }^{2}$.

6

7

8

9

10

11

12

13

14

15

16

17

18

19

20

21

\section{anaerobic nitrate-dependent iron oxidation}

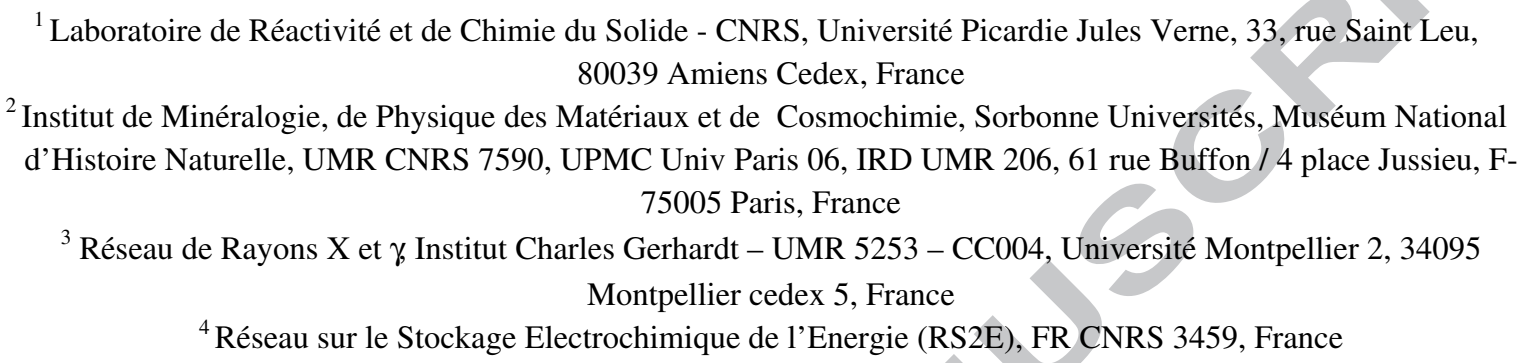


4 Biomineralization of magnetite is a central geomicrobiological process that might have played 5 a primordial role over Earth's history, possibly leaving traces of life in the geological record 6 or controlling trace metal(loid)s and organic pollutants mobility in modern environments. 7 Magnetite biomineralization has been attributed to two main microbial pathways to date 8 (namely magnetotactic bacteria and dissimilatory iron-reducing bacteria). Here, we uncover a 9 new route of magnetite biomineralization involving the anaerobic nitrate-reducing iron(II) 10 oxidizing bacterium Acidovorax sp. strain BoFeN1. Using transmission electron microscopy, 11 scanning transmission X-ray microscopy, transmission Mössbauer spectroscopy and rock magnetic analyses, this strain is shown to promote the transformation of hydroxychloride green rust in equilibrium with dissolved $\mathrm{Fe}(\mathrm{II})$ to (1) periplasmic lepidocrocite $(\gamma \mathrm{FeOOH})$ and (2) extracellular magnetite, thus leading to strong redox heterogeneities at the nanometer scale. On the one hand, lepidocrocite was associated with protein moieties and exhibited an anisotropic texture, with the elongated axis parallel to the cell wall. On the other hand, magnetite crystals exhibited grain sizes and magnetic properties consistent with stable single domain particles. By comparison, abiotic controls led to a very slow (4 months vs. 2 days in BoFeN1 cultures) and incomplete oxidation of hydroxychloride green rust towards magnetite. As this abiotic magnetite exhibited the same size and magnetic properties (stable single domain particles) as magnetite produced in BoFeN1 cultures, only the co-occurrence of textured $\mathrm{Fe}(\mathrm{III})$-oxides and magnetite, associated with the persistence of organic carbon molecules, might constitute valuable biosignatures to be looked for in the geological record.

24 Our results furthermore contribute to a more complex picture of Fe redox cycling in the environment, providing an additional process of $\mathrm{Fe}(\mathrm{II})$-bearing phase biomineralization that is not specific of Fe bio-reduction, but can also result from Fe bio-oxidation.

28 Keywords : biomineralization, magnetite, green rust, anaerobic iron oxidation, denitrification, biosignature. 
The evolution of iron-oxidizing and iron-reducing bacteria is intimately associated with changes in Fe redox cycling and bioavailability over geological timescales (Konhauser et al., 2011; Ilbert and Bonnefoy, 2013). Biominerals produced by these bacteria are thus widely used to reconstruct the evolution of paleo-environments and in particular the deep changes that occurred around the Great Oxidation Event (GOE) some 2.3 Ga ago (Anbar et al., 2007; Kump, 2008; Rasmussen et al., 2008; Konhauser et al., 2009; Frei et al., 2009; Scott et al., 2011; Czaja et al., 2012). Deciphering the characteristics and mineralogy of the phases that are produced by metabolisms relevant to this period of Earth's history is thus crucial in order to assess the mechanisms and environmental conditions that prevailed at the time of ironbearing phase deposition in the past.

Magnetite $\left(\mathrm{Fe}_{3} \mathrm{O}_{4}\right)$ is a common mineral in the geological record as well as in modern environments. For example, huge sedimentary iron deposits known as Banded Iron Formation (BIF) that have been deposited during the Precambrian contain a diversity of Fe-bearing minerals, among which magnetite (Posth et al., 2013; Li YL et al., 2013; Konhauser et al., 2002). Its genesis has been interpreted as the result of a combination of abiotic and biologically-driven $\mathrm{Fe}(\mathrm{II})$-oxidation and $\mathrm{Fe}(\mathrm{III})$-reduction reactions, occurring before and during diagenesis (Morris, 1993; Klein, 2005; Pecoits et al., 2009; Heimann et al., 2010; Papineau et al., 2010; Li et al., 2011, Li YL et al., 2013). In another context, magnetite is the main carrier of remanent magnetization in soils, commonly used for paleoenvironmental reconstructions (e.g. Chang et al., 2012, Roberts et al., 2011; Yamazaki and Shimono, 2013). Finally, magnetite also takes part in the control of pollutant mobility in modern environments (e.g. Wang et al., 2011; Morin et al. 2009; Morin et Calas, 2006).

Biomineralization of magnetite is commonly attributed to two types of bacteria, namely magnetotactic bacteria (MTB) and dissimilatory iron reducing bacteria (DIRB) (Li JH et al., 2013). The former produce intracellular magnetite with finely controlled size and morphology (Blakemore, 1975; Isambert et al., 2007; Li et al., 2010; Komeili, 2012), whereas the latter produce exclusively extracellular magnetite, usually exhibiting more widely distributed sizes. In addition, magnetic properties strongly differ between magnetites produced by (1) MTB that are stable single domain (SD), hence contributing to natural remanence magnetization (NRM) in soils, sediments and sedimentary rocks and (2) DIRB that are usually superparamagnetic (SP), i.e. of smaller size and with non-permanent 
1 magnetization (Jimenez-Lopez et al., 2010). Extracellular SD or even larger magnetite has 2 only been described in cultures of DIRB under specific conditions, for instance Geobacter 3 metallireducens GS-15 grown in the absence of $\mathrm{CO}_{2}$ in the cell culture headspace (Vali, 4 2004), and Thermoanaerobacter spp. strain TOR39 at elevated temperatures (e.g., $65^{\circ} \mathrm{C}$ ) 5 (Zhang et al., 1998) and/or after prolonged incubation (e.g., $65^{\circ} \mathrm{C}$ and 2 years) (Li YL, 2012).

The formation of magnetite by $\mathrm{Fe}(\mathrm{II})$-oxidizing bacteria and their crystallographic and 7 magnetic properties have never been clearly assessed. One study tentatively suggested that 8 this phase might have been produced among mixtures of Fe-oxides and phosphates in cultures 9 of a nitrate-reducing bacterium based on XRD data (Chaudhuri et al., 2001). However, as 10 already underlined (e.g. Pantke et al., 2012), some of the main XRD peaks of magnetite were 11 absent and the relative intensity of the other peaks not consistent with this mineral. (Jiao et al., 2005) suggested that the photoautotrophic Fe(II)-oxidizing bacterium Rhodopseudomnas palustris, strain TIE-1 biomineralized magnetite at $\mathrm{pH}>7.2$. However, this previous study did not provide any detailed mineralogical nor magnetic characterization of biomineralized magnetite. Furthermore, the spatial relationship between minerals and bacteria remain unknown.

Apart from biological pathways, different abiotic routes lead to the formation of magnetite. Among them, magnetite formation can result from the oxidation of green rust (GR). GRs are $\mathrm{Fe}(\mathrm{II})-\mathrm{Fe}(\mathrm{III})$-hydroxides with the general formula $\left[\mathrm{Fe}(\mathrm{II})_{1-\mathrm{x}} \mathrm{Fe}(\mathrm{III})_{\mathrm{x}}(\mathrm{OH})_{2}\right]^{\mathrm{x}+}$ $\left[(\mathrm{x} / \mathrm{n}) \mathrm{A}^{\mathrm{n}-}(\mathrm{m} / \mathrm{n}) \mathrm{H}_{2} \mathrm{O}\right]^{\mathrm{x}-}$, composed of brucite-like hydroxide layers alternating with anions (e.g. carbonate, chloride, formate or sulphite in GR type 1 referred to as GR1 or sulfate, selenate in GR type 2 referred to as GR2) and water molecules in the interlayer space. Abiotic green rust oxidation is kinetically controlled and leads to either lepidocrocite, goethite, magnetite or ferric hydroxycarbonate depending on $\mathrm{pH}$ conditions and the nature and concentration of the oxidant (e.g. Hansen et al., 1996; Ruby et al., 2010). In the present study, we use the anaerobic nitrate-reducing Fe(II)-oxidizing bacteria Acidovorax sp. strain BoFeN1. This strain has been shown to biomineralize goethite (Kappler et al., 2005; Schädler et al., 2009), 28 lepidocrocite (Larese-Casanova et al., 2010), Fe(III) phosphates (Miot et al., 2009a) as well as 29 some mixed $\mathrm{Fe}(\mathrm{II})-\mathrm{Fe}(\mathrm{III})$ phases, such as hydroxycarbonate green rust (Pantke et al., 2012) and $\mathrm{Fe}(\mathrm{II})-\mathrm{Fe}(\mathrm{III})$ phosphates with various $\mathrm{Fe}(\mathrm{II}) / \mathrm{Fe}(\mathrm{III})$ ratios (Miot et al., 2009b) depending on culture conditions. Recent findings show that Fe oxidation by this strain and other nitratereducing $\mathrm{Fe}(\mathrm{II})$-oxidizing bacteria is highly dependent on the release of nitrite as an intermediate of nitrate reduction (Klueglein and Kappler, 2013; Kopf et al., 2013; Carlson et 
1 al., 2013, Etique et al. 2014), in agreement with previous observations of the periplasmic

2 localization of $\mathrm{Fe}(\mathrm{III})$ minerals upon Fe(II) oxidation (Miot et al., 2011).

3 Here, we report the oxidation of hydroxychloride green rust to a mixture of 4 lepidocrocite and SD magnetite in cultures of the anaerobic nitrate reducing iron-oxidizing 5 bacteria Acidovorax sp, strain BoFeN1 and discuss what these results involve for the search of 6 biosignatures in geological samples.

\section{MATERIALS AND METHODS}

\subsection{Culture conditions and sample preparation} by culture on agar plates, of around $10^{5}$ colony-forming units / $\mathrm{mL}(\mathrm{CFU} / \mathrm{mL})$ ). Phosphate was provided as $\mathrm{KH}_{2} \mathrm{PO}_{4}$ at a concentration of $4.3 \mathrm{mM}$. Acetate $(5 \mathrm{mM}$ sodium acetate) and nitrate (10 $\mathrm{mM}$ sodium nitrate) were provided as a carbon source and as a terminal electron acceptor, respectively. After 2 days, bacteria were harvested by centrifugation (5000 g, 15 $\min$ ) and rinsed twice in 0.6 g. $\mathrm{L}^{-1} \mathrm{NaCl}$.

For biomineralization experiments, a specific medium was prepared composed of $\mathrm{NaCl}(11.4 \mathrm{mM})$, Na-acetate $(5 \mathrm{mM})$ and $\mathrm{FeCl}_{2}(10 \mathrm{mM})$, supplemented with vitamins, trace elements and selenite solutions prepared after (Ehrenreich and Widdel, 1994). This medium did not contain phosphate and was thus not designed for bacterial growth. The $\mathrm{pH}$ was adjusted at 7.6 with $\mathrm{NaOH} . \mathrm{NaNO}_{3}(10 \mathrm{mM})$ was then added leading to the precipitation of a green phase that was shown by X-ray diffraction (XRD) to consist of green rust (Fig. 1). Precultured rinsed bacteria were inoculated at $50 \%(\mathrm{v} / \mathrm{v})$ in this biomineralization medium (leading to an initial optical density at $600 \mathrm{~nm}$ of 0.109). Cultures prepared in 1L-flasks,

31 closed under $\mathrm{N}_{2}$ atmosphere with a butyl rubber stopper and crimped, were incubated at $30^{\circ} \mathrm{C}$ in the dark. Abiotic controls were prepared exactly the same way, unless addition of bacteria was omitted. 
Precipitates were collected from bacterial cultures and abiotic controls at t0 (i.e. before

2 inoculation of bacteria) and after 3 hours to 4 months by centrifugation $(6500 \mathrm{~g}, 15 \mathrm{~min})$, 3 rinsed twice with milli-Q water (with $\mathrm{pH}$ adjusted to 7.6 by addition of $\mathrm{NaOH} / \mathrm{HCl} 0.1 \mathrm{M}$ ) 4 and vacuum-dried inside the glovebox.

5 All samples studied were collected from the same batch, unless for the following analyses: (a)

6 the 5-day old cultures used for magnetic measurements, (b) samples used for TEM imaging of

7 thin sections, and (c) 2-day old cultures used for STXM analyses, were collected from

8 separate cultures. All samplings were performed under anoxic conditions in a glovebox.

\subsection{Analytical methods}

The bulk $\mathrm{Fe}(\mathrm{II}) / \mathrm{Fe}(\mathrm{III})$ ratio was determined in the solid phase. Precipitates were harvested by centrifugation (6500 g, $15 \mathrm{~min}$ ), rinsed twice in degassed milli-Q water (pH adjusted to 7.6) and vacuum-dried in the anoxic chamber. The solid was then dissolved in $6 \mathrm{M}$ $\mathrm{HCl}$ and iron contents were determined spectrophotometrically at $562 \mathrm{~nm}$ using the ferrozine assay (Viollier et al., 2000), either after dilution in $1 \mathrm{M} \mathrm{HCl}$ (for determining $\mathrm{Fe}(\mathrm{II})$ content) or using hydroxylamine- $\mathrm{HCl}$ as a reducing agent (for the determination of $\mathrm{Fe}$ (II)+Fe(III) content).

\subsection{Mineral characterization by X-ray diffraction}

The bulk mineralogy was determined by X-ray diffraction (XRD) of the solid phases collected by centrifugation $(5500 \mathrm{~g}, 15 \mathrm{~min})$ at different stages of the experiments. Samples were rinsed twice with degassed milli-Q water ( $\mathrm{pH}$ adjusted to 7.6) and vacuum dried. The powder was ground in an agate mortar, re-suspended in a small volume of degassed milli-Q water and placed in an anoxic cell equipped either with a Kapton or a beryllium window in a glovebox under $\mathrm{N}_{2} / \mathrm{H}_{2}(95 \%$ / 5\%) or $\mathrm{Ar}$ atmosphere. This preparation guaranteed strictly anoxic conditions over the duration of XRD measurements.

XRD measurements were performed with Co K $\alpha$ radiation $\left(\lambda_{1}=1.78897 \AA, \lambda_{2}=\right.$ $1.79285 \AA$ ) on either a Panalytical X'Pert Pro MPD diffractometer equipped with an $\mathrm{X}^{\prime}$ celerator ${ }^{\circledR}$ detector mounted in Bragg-Bertano configuration or on a Bruker D8 Advance diffractometer equipped with a Vantec detector. A continuous collection mode was applied over the $10-60^{\circ} 2$ trange with a $0.033^{\circ} 2$ estep and a total counting time of $1 \mathrm{~h} 30$. 


\subsection{Transmission Mössbauer spectroscopy}

3

4

${ }^{57} \mathrm{Fe}$ Transmission Mössbauer spectra were measured with a source of ${ }^{57} \mathrm{Co}$ in rhodium metal. The measurements were performed at room temperature (both the source and the absorber at $294 \mathrm{~K}$ ). For all measurements the spectrometer was operated with a triangular velocity waveform, and a $\mathrm{NaI}$ scintillation detector was used for the detection of gamma rays. The spectra were fitted with Lorentzian lines using the PC-Mos II computer program (Grosse, 1993). The absorbers were prepared in an Ar filled glovebox by mixing $20 \mathrm{mg}$ of the powder with $80 \mathrm{mg}$ of boron nitride as a binder and packed in sealed coffee-bags to avoid any contact with the ambient atmosphere during spectra acquisition. The isomer shift values are given relative to $\alpha \mathrm{Fe}$ standard at room temperature.

\subsection{Microscopy analyses}

Two types of samples were prepared for TEM analyses.

First, ultrathin sections were prepared by ultramicrotomy. Cells were fixed for $2 \mathrm{~h}$ in $1 \%$ glutaraldehyde at $4^{\circ} \mathrm{C}$, centrifuged (5000 g $-10 \mathrm{~min}$ ), rinsed three times in $20 \mathrm{mM}$ HEPES buffer $(\mathrm{pH} 7.5)$ for $18 \mathrm{~h}$ at $4^{\circ} \mathrm{C}$. They were then post-fixed for $90 \mathrm{~min}$ in $1 \% \mathrm{OsO}_{4}$ in the same buffer, rinsed three times in distilled water, dehydrated in graded ethanol and propylene oxide-1, 2 and progressively embedded in epoxy resin (Epoxy, Sigma). Ultrathin sections (40$\mathrm{nm}$ thick) were cut with a LEICA ultramicrotome (EM-UC6). After deposition on copper grids, they were stained with uranyl acetate $(2 \% \mathrm{w} / \mathrm{v})$.

Secondly, for scanning transmission electron microscopy (STEM), TEM and highresolution TEM (HRTEM), whole cells were deposited on a carbon-coated 200-mesh copper grid after 2 rinses in degassed milli-Q water and stored under $\mathrm{N}_{2}$ before analysis. STEM, TEM and HRTEM observations were performed with a field emission gun (FEG) JEOL2100F microscope operating at $200 \mathrm{kV}$. STEM observations were performed in highangle annular dark field (HAADF) mode. Selected-area electron diffraction (SAED) patterns were obtained on areas of interest. Magnetite particle sizes were measured on at least 100 particles on TEM images.

For scanning electron microscopy (SEM) observations, samples were prepared by depositing a drop of the rinsed culture (or abiotic sample) on a stub. Samples were carbon coated before analysis. SEM pictures were recorded using a Zeiss Ultra 55 SEM equipped 
1 with a field emission gun in secondary electron or back-scattered electron modes at 5 and 15

$2 \mathrm{kV}$ respectively and at working distances of 3 and $7.5 \mathrm{~mm}$ respectively.

\subsection{Scanning Transmission X-Ray Microscopy}

Samples were prepared and stored under anoxic conditions before analysis as described earlier (Miot et al., 2009a). Briefly, rinsed samples were deposited on silicon nitride window fixed on an aluminum sample holder, and covered with a second $\mathrm{Si}_{3} \mathrm{~N}_{4}$ window sealed to the first one with araldite. Samples were transferred to the microscope under $\mathrm{N}_{2}$ flow and the microscope chamber was then flushed with helium.

Part of the STXM analyses at the Fe $\mathrm{L}_{2,3}$ edges were performed at the Advanced Light Source (Lawrence Berkeley National Laboratory, Berkeley, USA). Other analyses at the Fe $\mathrm{L}_{2,3}$ edges as well as analyses at the $\mathrm{C} \mathrm{K}$-edge were performed at the 10ID-1 beamline at the Canadian Light Source (CLS, Saskatoon). More details about beamline at the ALS can be found in (Bluhm et al. 2006) and about beamline 10ID-1 at the CLS in (Kaznatcheev et al., 2007). Both beamlines have an energy resolving power $E / \mathbf{E}>3000$. The energy scales for this study were calibrated using the well-resolved 3p Rydberg peak of gaseous $\mathrm{CO}_{2}$ for the $\mathrm{C}$ K-edge and the major peak of hematite at $708.5 \mathrm{eV}$ for the $\mathrm{Fe}_{3}$-edge.

Data acquisition was performed at the $\mathrm{C} \mathrm{K}$-edge and at the $\mathrm{Fe} \mathrm{L}_{2,3}$-edges as described in (Miot et al., 2009a). Data (stacks and Near-Edge X-ray Absorption Fine Structure (NEXAFS) spectra) were processed using the aXis2000 software-package (Hitchcock, 2001) as described in (Miot et al., 2009a). More recent analytical details on STXM data processing for Fe redox state investigation can be found in (Bourdelle et al., 2013). A review on the use of STXM for characterizing biomineralizing systems and details on the type of information that can be retrieved is provided by Cosmidis and Benzerara (2014).

\subsection{Magnetic measurements}

Samples collected from bacterial cultures and the abiotic control were rinsed twice in degassed milli-Q water, dried under vacuum and stored under $\mathrm{N}_{2}$ in sealed aluminum pockets before analyses. To avoid oxidation, the cell sample preparation was conducted within an anoxic chamber.

Rock magnetic measurements were performed as described in $\mathrm{Li} \mathrm{JH}$ et al. (2012). 
1 vibrating sample magnetometer (Princeton Measurements Corporation VSM3900, sensitivity $2=0.5 \times 10^{-9} \mathrm{Am}^{2}$ ). FORCs (Pike et al., 1999; Roberts et al., 2000) were measured following 3 the protocol as described by Roberts et al. (2000). For each sample, a total of 120 FORCs 4 were measured with a positive saturation field of $1000 \mathrm{mT}$, an increasing field step $(\delta H)$ of $51.87 \mathrm{mT}$, and an averaging time of $200 \mathrm{~ms}$. The FORC diagrams were calculated using the 6 FORCinel version 1.22 software with a smoothing factor of 3 (Harrison and Feinberg, 2008).

7 The FORC characteristic coercivity $\left(B_{\mathrm{c}, \mathrm{FORC}}\right)$ is given by the median coercivity of the 8 marginal coercivity distribution (Harrison and Feinberg, 2008). Compared with other rock 9 magnetism methods such as conventional hysteresis loop, the FORC method simultaneously 10 incorporates information regarding magnetostatic interaction, microcercivity and domain state 11 of particles (e.g., Li JH et al., 2012; Li JH et al., 2013).

12 Low-temperature magnetic measurements were performed with a Quantum Design 13 Magnetic Property Measurement System (MPMS XP-5, sensitivity $=5.0 \times 10^{-10} \mathrm{Am}^{2}$ ) under vacuum. ZFC and FC curves were obtained by cooling samples from $300 \mathrm{~K}$ to $10 \mathrm{~K}$ in zero field and in a 2.5-T field, respectively, followed by imparting a saturation isothermal remanent magnetization SIRM in a 2.5-T field (hereafter termed as SIRM $_{10 K_{-} 2.5 T}$ ), and then measuring the remanence in zero field during warming to $300 \mathrm{~K}$.

\section{RESULTS}

Adjusting the $\mathrm{pH}$ of the biomineralization medium to 7.6 in the presence of $10 \mathrm{mM}$ nitrate led to massive precipitation of a dark green phase, identified by X-ray diffraction (XRD) (Fig.

\subsection{Evolution of the mineralogy upon green rust oxidation in BoFeN1 cultures} 1). The prominent peaks of this solid phase with $d$-spacings at $d_{003}=7.92 \AA$ and $d_{006}=3.97 \AA$ correspond to those of hydroxychloride green rust, $\mathrm{GR}(\mathrm{Cl})$, in accordance with the trigonal symmetry $R \overline{3} m$ and computed unit cell parameters (hexagonal axes) $a=0.319$ $\mathrm{nm}$ and $c=2.385 \mathrm{~nm}$ reported by Refait et al. (1998).

In biomineralization experiments with BoFeN1, bacterial growth was very limited (optical density at $600 \mathrm{~nm}$ evolved from 0.109 up to 0.131 over one week), which can be attributed to the composition of the biomineralization medium (absence of phosphate) that was not designed to not promote bacterial growth. The starting precipitate turned into a mixture of 
1 precipitate that adhered to a magnetic rod. This is consistent with the mineralogy obtained 2 from XRD analyses indicating a mixture of lepidocrocite $(\gamma \mathrm{FeOOH})$ and magnetite $\left(\mathrm{Fe}_{3} \mathrm{O}_{4}\right)$ in 3 the 4-day old BoFeN1 culture (Fig. 1). Accordingly, the $\mathrm{Fe}(\mathrm{II}) /(\mathrm{Fe}(\mathrm{II})+\mathrm{Fe}(\mathrm{III}))$ ratio in the solid phase rapidly dropped from 60 to $20 \%$ (i.e. bulk Fe redox state $=\mathrm{Fe}^{2.8+}$ ) as indicated by 5 ferrozine analyses.

6 The end-products in the BoFeN1 4-day old culture (mixture of lepidocrocite and 7 magnetite) were further characterized by transmission Mössbauer spectroscopy (TMS) at 8 room temperature (RT) (Fig. 2, Table 1). The Mössbauer spectrum exhibited two sextets $S_{A}$ 9 and $S_{B}$ with hyperfine magnetic fields $H$ of $48.7 \mathrm{~T}$ and $45.4 \mathrm{~T}$ corresponding to magnetite (90\%) (McCammon, 1995; Vandenberghe et al., 2000) and a doublet $D \gamma$ with hyperfine parameters $\left(\delta=0.37 \mathrm{~mm} . \mathrm{s}^{-1}, \Delta=0.61 \mathrm{~mm} . \mathrm{s}^{-1}\right)$ similar to those reported for lepidocrocite $(10 \%)$ (Ona-Nguema et al., 2002; Mitov et al., 2002; McCammon, 1995). Based on the best fit of this spectrum, there was a deficit of $\mathrm{Fe}^{2+}$ ions in the octahedral sites of magnetite with $39 \%$ of $\mathrm{Fe}^{3+}$ ions in the tetrahedral site (defined by $\delta=0.30 \mathrm{~mm} . \mathrm{s}^{-1}$ and $\varepsilon=-0.02 \mathrm{~mm} . \mathrm{s}^{-1}$ ) vs. $51 \%$ $\left(\mathrm{Fe}^{2+}+\mathrm{Fe}^{3+}\right)$ ions in the octahedral site (defined by $\delta=0.63 \mathrm{~mm} \cdot \mathrm{s}^{-1}$ and $\varepsilon=0.02 \mathrm{~mm} \cdot \mathrm{s}^{-1}$ ), consistent with non-stoichiometric magnetite. The $\mathrm{Fe}(\mathrm{II}) / \mathrm{Fe}(\mathrm{III})$ ratio in magnetite was thus estimated to be 0.4 from TMS data. Moreover, the flat baseline of the TMS signal supports the absence of small super-paramagnetic iron oxides. Given the relative proportions of lepidocrocite and magnetite in this sample (10/90) deduced from Mössbauer data, the bulk Fe redox state in the solid phase was thus estimated to be $\mathrm{Fe}^{2.8+}$ from TMS data, which is similar to the value deduced from acid-extraction Fe(II) measurements (ferrozine assay).

The evolution of the mineralogy was followed at the sub-micrometer scale by (HR)TEM in cultures of BoFeN1. As shown in Fig. 3, GR particles of a few tens of nanometers were still present in the culture medium after 15 hours as determined by SAED of single crystals. Their morphology exhibited however defects and was never perfectly octahedral. Intermediate stages of GR transformation into lath-shaped lepidocrocite were observed in the vicinity of the cells in 15-hour old samples (Fig. 3B). In contrast, only lepidocrocite was identified by SAED directly at the cell contact from 15 hours on. This phase persisted over 
1 of BoFeN1 cells as observed in ultramicrotomy sections (Fig. 3F to $\mathrm{H}$ ). This lepidocrocite 2 layer exhibited a thickness of $19 \pm 10 \mathrm{~nm}$, consistent with the thickness of the periplasm. In 3 addition, lepidocrocite particles exhibited a crystallographic orientation within the cell wall, the crystals being parallel to the direction of the membranes (Fig. 3G to I). In 38-hour old cultures, some magnetite crystals started to form at the contact of the GR particles (Fig. 3C, 3D) at distance from the bacteria (i.e. not at the cell surface). After 2 days, single crystals of magnetite were observed by TEM and SAED (Fig. 3E). The mean size of the magnetite particles increased slightly from $48 \pm 17 \mathrm{~nm}$ to $55 \pm 15 \mathrm{~nm}$ between 15 days and 4 months, with a shape factor (width/length) around 0.8-1.0 (Fig. 4A and 4B), thus ranging within the SD range (Butler and Banerjee, 1975; Muxworthy and Williams, 2009). Finally, in 4-month old samples, magnetite particles consisted of single crystals (Fig. 3J to 3L and Fig. 5A and 5B) with some defects or aggregation, as deduced from SEM, HRTEM and SAED analyses.

The iron oxidation state of particles in 3-hour to 4-month old BoFeN1 samples was further studied at the sub-micrometer scale using STXM at the Fe- $\mathrm{L}_{2,3}$ edges (Fig. 6). NEXAFS spectra measured on the starting green rust $(\mathrm{t}=0)$ exhibited main absorption peaks at $708 \mathrm{eV}$ and $710.1 \mathrm{eV}$, consistently with a mixed valence Fe phase, as well as special features previously described at the $\mathrm{Fe}_{2}$ edge for GR (shoulders at 719.5 and $723.3 \mathrm{eV}$ and double peak centered around $721 \mathrm{eV}$ ) (Pantke et al., 2012).

After 3 hours, the spectrum measured at the $\mathrm{Fe}_{2,3}$ edges on the bacterium was well fitted with a mixture of lepidocrocite $(17 \%)$ and green rust (83 \%) (Fig. 6A-G). This can be interpreted either as the coexistence of GR and lepidocrocite on the bacteria or as the presence of an intermediate oxidized GR phase or as the persistence of the initial Fe(III) (hydr)oxide evidenced by TMS in the starting material. After 1 day, NEXAFS spectra recorded on the bacteria exhibited a main absorption peak at $710.1 \mathrm{eV}$, consistent with lepidocrocite, in agreement with TEM data. After 15 days, the culture consisted of a mixture of magnetite and lepidocrocite, with lepidocrocite being localized exclusively at the cell contact and magnetite at some distance from the cells (Fig. 6D-F). This mineralogical pattern persisted in 4-month 28 old samples.

STXM analyses at the C K-edge showed the association of lepidocrocite with organic carbon, dominated by proteic moieties (Fig. 7). The map obtained by subtracting the image at $280 \mathrm{eV}$ from the image at $288.2 \mathrm{eV}$ thus corresponds mainly to the signature of amide carbonyl groups (peptidic bonds) in proteins (Benzerara et al. 2004b, Fig. 7). Based on spectroscopy at the C K-edge, no extracellular organic C signature (e.g. indicative of EPS) could be clearly detected in these samples. 


\subsection{Evolution of mineralogy and Fe redox state down to the nm-scale in abiotic control}

In the abiotic control, no change in the color of the precipitate was detected after 3 days, in agreement with the persistence of GR as the sole XRD-crystalline phase (Fig. 1) and by the absence of significant further oxidation of solid $\mathrm{Fe}(\mathrm{II})$ as deduced from acid-extracted $\mathrm{Fe}$ analyses of the solid phases. The kinetics of abiotic transformation of the initial precipitate into magnetite were many orders slower than in BoFeN1 cultures, with the first detection of magnetite observed by XRD only after 4 months (Fig. 1). This transformation might be attributed to slow diffusion of the XRD-amorphous Fe(III)-(hydr)oxide within the solution and subsequent reaction with $\mathrm{GR}(\mathrm{Cl})$.

Single crystals of magnetite obtained after 4 months exhibited a rather narrow size distribution, with a mean length of $94 \pm 18 \mathrm{~nm}$ and a shape factor of 0.8-1.0 (Fig. 4 C), consistent with the range size of SD magnetite (Butler and Banerjee, 1975; Muxworthy and Williams, 2009). These crystals laid at the surface of a poorly electron-dense phase (Fig. 3M to O). The nature of this phase was further elucidated by STXM.

STXM data at the $\mathrm{Fe} \mathrm{L}_{2,3}$ edges showed the coexistence of magnetite with an $\mathrm{Fe}(\mathrm{II})$-rich mixed valence phase, the NEXAFS spectrum of which exhibited the typical features of GR (Fig. $6 \mathrm{H}$ to $5 \mathrm{~K}$ ). These results suggested the persistence of a GR-like phase, which was not detected by XRD, most probably because of too low concentration.

\subsection{Magnetic properties of Fe-bearing phases}

Magnetic properties of Fe-bearing phases were examined over the course of the BoFeN1 cultures and in the abiotic control using FORC diagrams (Fig. 8). Consistently with TEM observations, the FORC diagrams showed a clear evolution of magnetite crystals from SP to SD particles with time (Carvallo et al., 2009; Li et al. 2009), consistently with the grain sizes measured by TEM (Fig. 4). The FORC diagram of 3-h old BoFeN1 culture is characterized by a small horizontal distribution $(<10 \mathrm{mT})$ and intersection with $B_{\mathrm{b}}$ axis with wide vertical distribution. This indicates that the magnetite is dominated by SP particles, along with a small fraction of particles with grain size around the threshold of SP/SD boundary. The FORC diagram of the 4-day old sample exhibits close concentric contours around a central peak, which is typical of SD particles (Pike et al., 1999; Roberts et al., 2000). Some contours still intersect with $B_{\mathrm{b}}$ axis, indicating co-occurrence of a small volume of SP particles. The wide 
1 vertical distribution (e.g., close to $\sim 20 \mathrm{mT}$ ) in the FORC diagram indicates strong magnetic 2 interactions within the samples (e.g., Pike et al., 1999; Roberts et al., 2000; Li JH et al., 3 2012), consistent with TEM observations of aggregates of extracellular magnetite. The 4 calculated characteristic $B_{\mathrm{c}, \mathrm{FORC}}$, which was recently demonstrated to be equal to remanence coercivity (e.g., Li JH et al., 2013b), is $2.0 \mathrm{mT}$ and $15.6 \mathrm{mT}$ for the 3-h and 4-day old samples, respectively. Low-temperature magnetic measurements (i.e., ZFC and FC curves) were performed to further characterize the magnetic anisotropy and chemical composition (i.e., stoichiometry) of BoFeN1 magnetite (e.g., Moskowitz et al., 1993; Kakol \& Honig, 1989; Li JH et al., 2012). Fig. 8c shows the thermal demagnetization curves of SIRM10K_2.5T for 4-day old BoFeN1 culture. Both ZFC and FC warming curves exhibit steep SIRM decay and intensity difference at temperatures lower than $30 \mathrm{~K}$, which results from unblocking behavior of SP particles and magnetic interactions within samples (e.g., Moskowitz et al., 1993; Li JH et al., 2012). Above $30 \mathrm{~K}, \mathrm{ZFC}$ shows identical behavior of thermal demagnetization to FC, and no obvious Verwey transition around 100-120 K is observed in both curves. The absence of Verwey transition could be explained by (1) the dominance of non-stoechiometric magnetite crystals within the 4-day old BoFeN1 culture, in accordance with TMS and FORC analyses (Fig. 2 and 8) and (2) the co-existence of SP particles (Muxworthy and McClelland, 2000; Wang and Lovlie, 2008). Moreover, the ZFCand FC-SIRM $10 \mathrm{~K}$ 2.5T warming curves obtained for BoFeN1 magnetites differ from that reported for magnetite produced by magnetotactic bacteria, which are generally controlled by shape anisotropy (Moskowitz et al., 1993; Li JH et al., 2012; Li JH et al., 2013a). In contrast, magnetic analyses of BoFeN1 magnetites indicate the absence of particles chains or of elongated crystals (magnetocrystalline anisotropy), in accordance with TEM observations of randomly aggregated cubic or spherical crystals (Fig. 3). The 4-month old BoFeN1 culture displays no obvious difference in magnetic behavior from the 4-day old sample (data not shown).

We also measured the FORC diagram of the 4-month old abiotic sample where magnetite crystals formed through slow oxidation of GR. As shown in Fig. 8d, abiotic magnetite exhibits similar magnetic properties as 4-day and 4-month old BoFeN1 magnetites, i.e., dominated by strongly interacting SD particles. The calculated $B_{\mathrm{c}, \text { FORC value of } \sim 16.4 \mathrm{mT}}$ indicates comparable crystal size distribution, crystallinity, and/or particle-particle interactions. 
4.1. Biomineralization of extracellular magnetite induced by nitrate-dependent iron oxidation.

Biomagnetite production by magnetotactic bacteria and $\mathrm{Fe}(\mathrm{III})$-reducing bacteria has been extensively studied (see Li JH et al., 2013a for a review). In contrast, whether magnetite can be formed by $\mathrm{Fe}(\mathrm{II})$-oxidizing bacteria remaind still unclear. Here, we experimentally evidence that the nitrate-reducing Fe(II)-oxidizing strain BoFeN1 can promote the formation of stable single domain magnetite.

This strain can form a diversity of Fe-bearing minerals depending on culture conditions: lepidocrocite is obtained at neutral pH (Larese-Casanova et al., 2010; Miot et al., 2014), whereas increasing $\mathrm{pH}$, phosphate or carbonate concentrations, as well as adding humic acids promote the formation of goethite (Kappler et al., 2005; Larese-Casanova et al., 2010). In addition, hydroxycarbonate green rust was shown to form as an intermediate product on the way to goethite biomineralization (Pantke et al., 2012). Eventually, in a medium rich in dissolved phosphate or in the presence of the solid Fe(II)-phosphate vivianite, amorphous Fephosphates, exhibiting varying $\mathrm{Fe}^{\mathrm{III}} /\left(\mathrm{Fe}^{\mathrm{II}}+\mathrm{Fe}^{\mathrm{III}}\right)$ ratios are obtained (Miot et al., 2009a; Miot et al., 2009b). Moreover, growth of magnetite crystals in cultures of BoFeN1 initially seeded with magnetite particles had also been reported (Dippon et al., 2012). In the present study, magnetite precipitation is induced by the activity of BoFeN1 under non-growth conditions, without the need for initial magnetite particles serving as nucleation sites. Our results not only add to the list of iron-bearing phases known to form in cultures of this bacterial strain, but also contribute to a more complex picture of Fe redox cycling, involving $\mathrm{Fe}(\mathrm{II})$-oxidizing bacteria in the formation of mixed valence Fe-bearing minerals.

The mechanisms of $\mathrm{Fe}(\mathrm{II})$ oxidation by nitrate-reducers is (at least partly) linked to the production of reactive intermediate nitrite molecules (Miot et al., 2011; Klueglein and 27 Kappler, 2013; Kopf et al., 2013; Carlson et al., 2013; Etique et al., 2014), thus potentially 28 extending the number of anaerobic strains able to promote Fe-bearing mineral formation to all nitrite-producing bacteria. Interestingly, magnetite biomineralization dependent upon the periplasmic nitrate reductase Nap has been recently evidenced in the magnetotactic bacterium Magnetospirillum gryphiswaldense MSR-1 (Li YJ et al., 2012), suggesting an intrinsic link between nitrate reduction and magnetite biomineralization in some magnetotactic strains. 
1 insights about the extent of the processes of magnetite biomineralization associated with 2 microbial nitrate reduction.

3

\subsection{Green rust transformation to magnetite and lepidocrocite promoted by BoFeN1}

Usually, GR oxidation proceeds either by dissolution reprecipitation or by in situ deprotonation (Ruby et al., 2010). At low redox potential, GR can directly transform to magnetite, with a concomitant release of dissolved Fe(II), whereas at higher redox potential, GR oxidation is complete, leading to the formation of $\mathrm{Fe}(\mathrm{III})$-oxyhydroxides, e.g. ferrihydrite. With carbonate green-rust, both reactions have been shown to occur through dissolutionreprecipitation processes (Ruby et al., 2010). In addition, dissolyed Fe(II) can further reductively transform $\mathrm{Fe}(\mathrm{III})$-oxyhydroxide to magnetite (Usman et al., 2012). All these considerations can be reconciled with our observations in the following scenario (Fig. 9): GR transformation depends on local oxidant concentration (i.e. redox potential) in cultures of BoFeN1. (1) At low oxidant concentration, $\mathrm{GR}(\mathrm{Cl})$ directly transforms to magnetite, involving a net release of dissolved $\mathrm{Fe}(\mathrm{II})$. (2) In parallel, at higher oxidant concentration, $\mathrm{GR}(\mathrm{Cl})$ transforms to $\mathrm{Fe}(\mathrm{III})$-oxyhydroxides (lepidocrocite), that further react with dissolved $\mathrm{Fe}$ (II) to transform to magnetite (Misawa et al., 1974). This last step is enhanced by the release of dissolved $\mathrm{Fe}$ (II) from the first reaction. In addition, periplasmic oxidation of dissolved Fe(II) by BoFeN1 (through reaction with nitrite, (Klueglein and Kappler, 2013, Kopf et al., 2013; Carlson et al., 2013) leads to periplasmic encrustation by lepidocrocite, enhancing the dissolution of GR by equilibrium displacement, hence promoting an increased extracellular dissolved $\mathrm{Fe}$ (II) concentration. Assessing the mechanisms of each of these steps will require a complete chemical mass balance (including $\mathrm{N}$ species tracking) as well as monitoring the redox potential over the course of the culture. In the end, heterogeneities in the mineralogy of this system may reflect heterogeneities in redox conditions induced by bacterial nitrate-reducing activity.

There are differences in the formation of magnetite between the abiotic control and BoFeN1 cultures: (1) the kinetics of the reaction are many orders more rapid in BoFeN1 cultures than in abiotic controls ( 3 days vs. 4 months) and (2) the transformation of GR is complete in the presence of BoFeN1 (no remaining GR could be detected by any of the methods used in this study) whereas it was incomplete in the abiotic sample as suggested by the persistence of an electron-light phase (Fig. 3) having a NEXAFS spectrum similar to GR at the $\mathrm{Fe} \mathrm{L}_{2,3}$-edge (Fig. 6). The very slow transformation of GR to magnetite in the abiotic 
1 control might be related to the slow diffusion of an amorphous Fe(III) (hydr)oxide phase

2 reacting with green rust (Fig. 4, Table 1) and/or to nitrate reduction (Hansen et al., 1996),

3 whereas nitrate might be much more rapidly reduced through bacterial activity in BoFeN1

4 cultures and thus unavailable for GR oxidation.

5

\subsection{Patterns of iron biomineralization}

TEM observations evidence the presence of a lepidocrocite layer at the periphery of the bacteria, exhibiting a thickness consistent with that of the periplasm. Such a periplasmic encrustation of BoFeN1 cells by Fe-bearing phases is also consistent with previous reports showing periplasmic encrustation of this strain by either Fe-phosphates (e.g. Miot et al., 2009a) or Fe-oxyhydroxides (e.g. Miot et al., 2014). These observations also add to the diversity of bacteria that were shown to localize biomineralization within the periplasm, leading to the formation of cells encrusted with phosphates (Benzerara et al., 2004a; Goulhen et al., 2005; Dunham-Cheatham et al., 2011; Cosmidis et al., 2013), oxides (Gloter et al., 2004; Benzerara et al., 2008) or sulfides (Donald and Southam, 1999).

Moreover, in the present study, periplasmic lepidocrocite crystals are strongly anisotropic, elongated parallel to the cell wall (Fig. 3). Such a crystallographic orientation within bacterial cell walls has also been reported for phosphates within the periplasm of Ramlibacter sp. (Benzerara et al., 2004a) and for hematite $\left(\alpha \mathrm{Fe}_{2} \mathrm{O}_{3}\right)$ obtained after heating encrusted BoFeN1 cells (Miot et al., 2014). Hence, the periplasm seems to control the crystallographic orientation of these biominerals.

We obserye that periplasmic lepidocrocite persists even after a few months, whereas one may expect conversion to magnetite by partial reduction by dissolved Fe(II). This might be explained either by an active control of $\mathrm{Fe}$ (II) traffic towards the periplasm, a protective role played by organic matter (e.g. Jones et al., 2009) or the trapping of dissolved Fe(II) through instantaneous reaction with extracellular Fe(III)-oxyhydroxides, i.e. before dissolved $\mathrm{Fe}(\mathrm{II})$ reaches the cell.

Magnetites produced in BoFeN1 cultures are dominantly controlled by magnetocrystalline anisotropy (i.e., cubic morphology) (Fig. 8), which is distinct from MTB magnetite usually controlled by shape anisotropy (particle elongation or/and chain structure) (Li JH et al. 2013a, Li JH et al., 2010). Moreover, the bulk Fe(II)/Fe(III) of magnetite in the BoFeN1 system is 0.4 as deduced from TMS data, i.e. magnetite is non-stoichiometric, slightly oversaturated with Fe(III). This differs strongly from what is known in other magnetite biomineralization 
1 pathways. Indeed, the obvious presence of Verwey transition behavior in magnetites produced 2 by magnetotactic bacteria suggests that they are close to stoichiometry, although all 3 magnetites from magnetotactic bacteria discovered thus far have reduced Verwey transition 4 temperature (i.e., $\sim 100-110 \mathrm{~K}$ ) compared to $\sim 120-125 \mathrm{~K}$ for chemically synthesized 5 magnetites (e.g. Moskowitz et al., 1993; Li JH et al. 2012). In contrast, nanomagnetite 6 produced by dissimilatory Fe(III)-reduction (cultures of Shewanella sp.) has been shown to be 7 oversaturated with $\mathrm{Fe}(\mathrm{II})$ compared with abiotic magnetite (Carvallo et al., 2008; Kukkadapu 8 et al., 2005; Coker et al., 2007).

Here, the $\mathrm{Fe}(\mathrm{II}) / \mathrm{Fe}(\mathrm{III})$ ratio estimated at the nm-scale in cultures of BoFeN1 reflects redox microenvironments controlled by bacterial Fe(II) oxidation and nitrate reduction, with lepidocrocite in the cell wall and magnetite at distance from the cells. Heterogeneous mineralization patterns reflecting redox microenvironments have been observed in other systems, e.g. in cultures of dissimilatory iron-reducing bacteria (Coker et al. 2012) or in cultures of photoferrotrophs (Miot et al., 2009c). However, in these previous studies, the mineralogy at the nm-scale was very different with (1) the coexistence of magnetite at the cell contact and maghemite-like phases at distance from the cells in cultures of the dissimilatory Fe(III)-reducing bacteria Shewanella oneidensis (Coker et al. 2012) and (2) the presence of nano-goethite exhibiting $\mathrm{Fe}(\mathrm{II}) / \mathrm{Fe}$ (III) gradients along lipopolysaccharidic fibers in cultures of Rhodobacter sp. strain SW2 (Miot et al. 2009c). Thus, the biomineralization patterns observed here at the nm-scale exhibit very specific features. increasingly thought to have played a quantitative role in the Fe redox biogeochemical cycle

\subsection{Implications for the search of biosignatures in the fossil record} on the early anoxic Earth, by promoting the precipitation of $\mathrm{Fe}(\mathrm{III})$-(oxyhydr)oxides

Anaerobic Fe(II)-oxidizing bacteria have been proposed to play an important role over (Konhauser et al., 2002; Posth et al., 2008; Planavsky et al., 2009; Czaja et al., 2013; Köhler et al., 2013). On the other hand, anaerobic nitrate-reducing iron(II)-oxidizers, whose activity might have been dependent upon nitrate advent in the nitrogen cycle under (at least locally) more oxidizing conditions (e.g. Ilbert and Bonnefoy, 2013; Busigny et al., 2013) can produce miscellaneous $\mathrm{Fe}(\mathrm{III})$-bearing minerals. Here, we uncover the production of stable SD magnetite by such nitrate reducers, whereas SD magnetite biomineralization has been usually 
1 attributed to the activity of magnetotactic bacteria ( $\mathrm{Li} \mathrm{JH}$ et al., 2013a). These results have

2 potential implications for the study of geomicrobiological processes occurring in past and 3 modern environments. Indeed, stable SD magnetite is the main carrier of stable remanent magnetization in some sediments and sedimentary rocks (Petersen et al., 1986; Chang, 1989; Roberts et al., 2012). Moreover, this mineral is widespread in the geological record, from the ancient Earth to modern environments. The potential role played by nitrite-producing bacteria should thus be taken into account when evaluating the processes responsible for magnetite biomineralization.

Past and modern geochemical systems involving green rust and magnetite are usually interpreted as to result from abiotic processes and/or from the activity of DIRB (Lovley et al., 1987). Our present study shows that microbial anaerobic iron oxidation can also play a role in such systems. Interestingly, the co-occurence of green rust and magnetite has been recently observed in the meromictic lake Matano considered as an analog of Precambrian oceans (Zegeye et al., 2012).

Magnetite is a major component of Banded Iron Formations (BIFs) (Klein, 2005), along with hematite and siderite. Growing evidence suggests that primary iron oxides originated from bacterial anaerobic iron oxidation (namely photoferrotrophy, e.g. Konhauser et al., 2002; Posth et al., 2008), although cyanobacteria-mediated $\mathrm{O}_{2}$ oxidation has also been proposed. Moreover, as an alternative or in addition to potential diagenetic origins (e.g. Morris, 1993; Pecoits et al., 2009), Fe(II)-bearing phases (e.g. siderite, magnetite) have been proposed to originate from $\mathrm{Fe}(\mathrm{III})$-(hydr)oxides bioreduction driven by DIRB. This biological origin is supported by isotopic compositions of Fe (Johnson et al., 2008; Heimann et al., 2010) and C (Papineau et al., 2010), crystallochemical (Li YL et al., 2011), and experimental data (Li YL et al., 2013). Potential involvement of anaerobic nitrate-reducing Fe(II)-oxidizing bacteria in the formation of magnetite in such past environments would have been dependent upon the availability of nitrate (i.e. upon the advent of atmospheric oxygenation, or locally $\mathrm{O}_{2}$-rich areas or any other - e.g. microbial - source of nitrate) in the Archean ocean (e.g. Busigny et 28 al., 2013).

Importantly, our study shows that magnetite exhibiting similar crystallochemical and magnetic properties could be obtained by an abiotic route at low temperature. Hence, none of the properties of magnetite produced by BoFeN1 can be held as a biosignature per se. However, the coexistence of (1) stable single domain magnetite with (2) lepidocrocite exhibiting a crystallographic orientation and a thickness consistent with that of a bacterial cell 
1 wall and (3) in association with protein moieties (or protein-derived moieties after diagenesis)

2 might represent a very specific feature to be looked for in the geological record. Such redox 3 heterogeneities at the nanometer-scale, associated with organic matter, and reflecting the 4 redox conditions imposed by bacterial activity have been previously reported in cultures of 5 iron-oxidizing bacteria (Miot et al., 2009a; Miot et al., 2009c) and suggested to provide 6 biosignatures of iron oxidizing metabolism. The evolution of such assemblages upon 7 diagenesis and metamorphism has to be evaluated but might preserve primary redox and 8 organic signatures (e.g. Bernard et al., 2007; Koehler et al., 2013). Indeed, heating 9 lepidocrocite mineralized $\mathrm{BoFeN} 1$ cells at $700^{\circ} \mathrm{C}$ in the air led to structures exhibiting an 10 intact bacterial morphology and composed of hematite crystallographically oriented parallel 11 to the cell wall (Miot et al., 2014). Preservation of organic carbon molecules in heated 12 mineralized BoFeN1 cells under anoxic conditions has also been recently observed ( $\mathrm{Li} \mathrm{JH}$ et 13 al. 2013a). Eventually, as shown by (Li YL et al., 2013) diagenetic conditions might induce magnetite crystal growth from a few tens of nm up to a few micrometers. hydroxychloride green rust oxidation promoted by the anaerobic nitrate-reducing ironoxidizing bacteria Acidovorax sp. strain BoFeN1. STXM analyses coupled with TEM observations evidence strong redox heterogeneities. Whereas lepidocrocite is mineralized within the bacterial periplasm and thus associated with protein moieties, stable single domain magnetite is precipitated extracellularly. By comparison, abiotic oxidation of green rust operating at much slower kinetics (4 months vs. 2 days) provides an incomplete transformation of hydroxychloride green rust to stable single domain magnetite, and does not produce lepidocrocite. Hence, the association of redox heterogeneities with the persistence of 28 organic compounds might constitute valuable biosignatures to be looked for in the rock record. In addition, this study uncovers a new pathway for magnetite biomineralization that should be taken into account when looking for the microbial processes involved in magnetite formation in past and modern environments. Eventually, this study stresses the importance of nitrite-producing bacteria in iron biogeochemistry and adds to the complexity of Fe redox cycling in the environment, which might have implications for the processes controlling pollutant mobility. 
The authors thank Matthieu Morcrette, Jean-Marie Tarascon, Dominique Larcher and Nadir Recham from the Laboratoire de Réactivité et Chimie des Solides (LRCS, Amiens), as well as Isabelle Domart-Coulon (MCAM, MNHN). Mélanie Poinsot (IMPMC) is acknowledged for help with bacterial culture. This study was funded by RS2E and by Actions Thématiques du Muséum - Biominéralisation grants. The JEOL JEM2100F at the IMPMC was bought with support from Region Ile de France grant SESAME 2000 E 1435, INSU CNRS, INP CNRS and University Pierre et Marie Curie Paris 6. The SEM facility of the IMPMC was bought with support from Region Ile de France grant SESAME 2006 I-07-593/R, INSU-CNRS, INP CNRS, and University Pierre et Marie Curie Paris 6. Part of the STXM analyses was performed at the Advanced Light Source (ALS) on beamline 11.0.2. The ALS Molecular Environmental Science beamline 11.0.2 is supported by the Office of Science, Office of Basic Energy Sciences, Division of Chemical Sciences, Geosciences, and Biosciences and Materials Sciences Division, U.S. Department of Energy, at the Lawrence Berkeley National Laboratory, under contract DE-AC03-76SF00098. Additional STXM measurements were carried out on beamline SM at the CLS. The Canadian Light Source is supported by NSERC, CIHR, NRC and the University of Saskatchewan. Rock magnetism measurements were performed at the Paleomagnetism and Geochronology Lab in Beijing (PGL-IGGCAS, China) and supported by the National Natural Science Foundation of China (NSFC grant No. 41374004). 


\section{Bibliography}

Anbar A. D., Duan Y., Lyons T. W., Arnold G. L., Kendall B., Creaser R. A., Kaufman A. J., Gordon G. W., Scott C., Garvin J. and Buick R. (2007) A Whiff of Oxygen Before the Great Oxidation Event? Science 317, 1903-1906.

Benzerara K., Menguy N., Guyot F., Skouri F., de Luca G., Barakat M. and Heulin T. (2004a) Biologically controlled precipitation of calcium phosphate by Ramlibacter tataouinensis. Earth Planet. Sci. Lett. 228, 439-449.

Benzerara K. Yoon T.H., Tyliszczak T., Constantz B., Spormann A.M., Brown Jr G.E. (2004b) Scanning transmission X-ray microscopy study of microbial calcification.

Geobiology, 2, 249-259.

Benzerara K., Morin G., Yoon T. H., Miot J., Tyliszczak T., Casiot C., Bruneel O., Farges F. and Brown G. E. (2008) Nanoscale study of As biomineralization in an acid mine drainage system. Geochim. Cosmochim. Acta 72, 3949-3963.

Bernard S., Benzerara K., Beyssac O., Menguy N., Guyot F., Brownjr G. and Goffe B. (2007) Exceptional preservation of fossil plant spores in high-pressure metamorphic rocks. Earth Planet. Sci. Lett. 262, 257-272.

Blakemore R. (1975) Magnetotactic bacteria. Science 190, 377-379.

Bluhm H. et al. (2006) Soft X-ray microscopy and spectroscopy at the molecular environmental science beamline at the Advanced Light Source. J. Electron Spectrosc. 150, 86-104.

Bourdelle F., Benzerara K., Beyssac O., Cosmidis J., Neuville D. R., Brown G. E. and Paineau E. (2013) Quantification of the ferric/ferrous iron ratio in silicates by scanning transmission X-ray microscopy at the Fe L2,3 edges. Contrib. Miner. Pet. Available at: http://link.springer.com/10.1007/s00410-013-0883-4 [Accessed July 15, 2013].

Busigny V., Lebeau O., Ader M., Krapez B., Bekker A. (2013) Nitrogen cycle in the Late Archean ferruginous ocean. Chem. Geol. 362(SI), 115-130.

Butler R.F., Banerjee S.K. (1975) Theoretical single-domain grain size range in magnetite and titano-magnetite. J. Geophys. Res. 80, 4049-4058.

Carlson H. K., Clark I. C., Blazewicz S. J., Iavarone A. T. and Coates J. D. (2013) Fe(II) Oxidation Is an Innate Capability of Nitrate-Reducing Bacteria That Involves Abiotic and Biotic Reactions. J. Bacteriol. 195, 3260-3268.

Carvallo C., Sainctavit P., Arrio M.A., Menguy N., Wang Y., Ona-Nguema G., Brice-Profeta S. (2008) Biogenic vs. abiogenic magnetite nanoparticles: a XMCD study. Am. Min. 93, 880885. 
1 Carvallo C., Hickey S., Faivre D., Menguy N. (2009) Formation of magnetite in

2 Magnetospirillum gryphiswaldense studied with FORC diagrams. Earth Planets Space, 61, 3 143-150.

4

5

Chang S. (1989) Magnetofossils, The Magnetization Of Sediments, And The Evolution Of Magnetite Biomineralization. Annu. Rev. Earth Planet. Sci. 17, 169-195.

Chang L., Roberts A.P., Williams W., Larrasoana J.C., Jovane L., Muxworthy A.R. (2012) Giant magnetofossils and hyperthermal events. Earth Planet. Sc. Lett. 351, 258-269.

Chaudhuri S. K., Lack J. G. and Coates J. D. (2001) Biogenic Magnetite Formation through Anaerobic Biooxidation of Fe(II). Appl. Environ. Microbiol. 67, 2844-2848.

Coker V.S., Pearce C.I., Lang C., van der Laan G., Pattrick A.D., Telling N.D., Schuler D., Arenholz E., Lloyd J.R. (2007) Cation site occupancy of biogenic magnetite compared to polygenic ferrite spinels determined by X-ray magnetic circular dichroism. Eur. J. Mineral. 19, 707-716.

Coker V.S., Byrne J.M., Telling N.D., Van der Laan G., Lloyd J.R., Hitchcock A.P., Wang J., Pattrick A.D. (2012) Characterization of the dissimilatory reduction of Fe(III)-oxyhydroxide at the microbe-mineral interface: the application of STXM-XMCD. Geobiology, 10, 347-354.

Cosmidis J., Benzerara K., Gheerbrant E., Estève I., Bouya B. and Amaghzaz M. (2013) Nanometer-scale characterization of exceptionally preserved bacterial fossils in Paleocene phosphorites from Ouled Abdoun (Morocco). Geobiology 11, 139-153.

Cosmidis J, Benzerara K. (2014) Soft X-ray Scanning Transmission Spectromicroscopy. In Biomineralization Sourcebook: Characterization of Biominerals and Biomimetic Materials, London, UK: E. DiMasi and L.B. Gower (Eds).

Czaja A. D., Johnson C. M., Beard B. L., Roden E. E., Li W. and Moorbath S. (2013) Biological Fe oxidation controlled deposition of banded iron formation in the ca. 3770Ma Isua Supracrustal Belt (West Greenland). Earth Planet. Sci. Lett. 363, 192203.

Czaja A. D., Johnson C. M., Roden E. E., Beard B. L., Voegelin A. R., Nägler T. F., Beukes N. J. and Wille M. (2012) Evidence for free oxygen in the Neoarchean ocean based on coupled iron-molybdenum isotope fractionation. Geochim. Cosmochim. Acta 86, 118137.

Dippon U., Pantke C., Porsch K., Larese-Casanova P. and Kappler A. (2012) Potential Function of Added Minerals as Nucleation Sites and Effect of Humic Substances on Mineral Formation by the Nitrate-Reducing Fe(II)-Oxidizer Acidovorax sp. BoFeN1. Environ. Sci. Technol. 46, 6556-6565.

Donald R. and Southam G. (1999) Low temperature anaerobic bacterial diagenesis of ferrous monosulfide to pyrite. Geochim. Cosmochim. Acta 63, 2019-2023.

Drissi S.H., Refait P., Abdelmoula M., Génin J.M.R. (1995) The preparation and thermodynamic properties of Fe(II)-Fe(III) hydroxide-carbonate (Green rust 1) - Pourbaix diagram of iron in carbonate-containing aqueous media. Corros. Sci. 37, 2025. 
Dunham-Cheatham S., Rui X., Bunker B., Menguy N., Hellmann R. and Fein J. (2011) The effects of non-metabolizing bacterial cells on the precipitation of $\mathrm{U}, \mathrm{Pb}$ and $\mathrm{Ca}$ phosphates. Geochim. Cosmochim. Acta 75, 2828-2847.

Ehrenreich A. and Widdel F. (1994) Anaerobic oxidation of ferrous iron by purple bacteria, a new type of phototrophic metabolism. Appl. Environ. Microbiol. 60, 4517-4526.

Etique M., Jorand F. P. A., Zegeye A., Grégoire B., Despas C. and Ruby C. (2014) Abiotic Process for Fe(II) Oxidation and Green Rust Mineralization Driven by a Heterotrophic Nitrate Reducing Bacteria (Klebsiella mobilis) Environ. Sci. Technol., 2014, 48, 3742-3751.

Frei R., Gaucher C., Poulton S. W. and Canfield D. E. (2009) Fluctuations in Precambrian atmospheric oxygenation recorded by chromium isotopes. Nature 461, 250-253.

Génin J.M.R., Bourrié G., Trolard F., Abdelmoula M., Jaffrezic A., Refait Ph., Maître V., Humbert B., Herbillon A. (1998) Thermodynamic equilibria in aqueous suspensions of synthetic and natural $\mathrm{Fe}(\mathrm{II})-\mathrm{Fe}(\mathrm{III})$ green rusts. Occurrences of the mineral in hydromorphic soils. Environ. Sci. Technol. 32, 1058.

Génin J.-M. R., Ruby C., Géhin A. and Refait P. (2006) Synthesis of green rusts by oxidation of $\mathrm{Fe}(\mathrm{OH}) 2$, their products of oxidation and reduction of ferric oxyhydroxides; $-\mathrm{pH}$ Pourbaix diagrams. Comptes Rendus Geosci. 338, 433-446.

Gloter A., Zbinden M., Guyot F., Gaill F. and Colliex C. (2004) TEM-EELS study of natural ferrihydrite from geological-biological interactions in hydrothermal systems. Earth Planet. Sci. Lett. 222, 947-957.

Goulhen F., Gloter A., Guyot F. and Bruschi M. (2005) Cr(VI) detoxification by Desulfovibrio vulgaris strain Hildenborough: microbe-metal interactions studies. Appl. Microbiol. Biotechnol. 71, 892-897.

Grosse G. (1993) PC-Mos II. Version 1.0. Fast ComTec, Oberhaching, Germany.

Hansen H. C. B., Koch C. B., Nancke-Krogh H., Borggaard O. K. and Sørensen J. (1996) Abiotic Nitrate Reduction to Ammonium: Key Role of Green Rust. Environ. Sci. Technol. 30, 2053-2056.

Harrison R. J. and Feinberg J. M. (2008) FORCinel: An improved algorithm for calculating first-order reversal curve distributions using locally weighted regression smoothing: FORCINEL ALGORITHM. Geochem. Geophys. Geosystems 9, n/a-n/a.

Heimann A., Johnson C. M., Beard B. L., Valley J. W., Roden E. E., Spicuzza M. J. and Beukes N. J. (2010) Fe, C, and O isotope compositions of banded iron formation carbonates demonstrate a major role for dissimilatory iron reduction in $\sim 2.5 \mathrm{Ga}$ marine environments. Earth Planet. Sci. Lett. 294, 8-18.

Hitchcock A.P. (2001) Soft X-ray spectromicroscopy of polymers and biopolymer interfaces. J. Synchrotron Radiat. 8, 66-71.

Ilbert M. and Bonnefoy V. (2013) Insight into the evolution of the iron oxidation pathways. Biochim. Biophys. Acta Bba - Bioenerg. 1827, 161-175. 
1 Isambert A., Menguy N., Larquet E., Guyot F., Valet J. P. (2007) Transmission electron 2 microscopy study of magnetites in a freshwater population of magnetotactic bacteria. Am. 3 Mineral., 92, 621-630.

4

5

6

Jiao Y., Kappler A., Croal L. R. and Newman D. K. (2005) Isolation and Characterization of
a Genetically Tractable Photoautotrophic Fe(II)-Oxidizing Bacterium,
Rhodopseudomonas palustris Strain TIE-1. Appl. Environ. Microbiol. 71, 4487-4496.

Jimenez-Lopez C., Romanek C. S. and Bazylinski D. A. (2010) Magnetite as a prokaryotic biomarker: A review. J. Geophys. Res. 115. Available at: http://doi.wiley.com/10.1029/2009JG001152 [Accessed September 8, 2013].

Johnson C. M., Beard B. L., Klein C., Beukes N. J. and Roden E. E. (2008) Iron isotopes constrain biologic and abiologic processes in banded iron formation genesis. Geochim. Cosmochim. Acta 72, 151-169.

Jones A. M., Collins R. N., Rose J. and Waite T. D. (2009) The effect of silica and natural organic matter on the $\mathrm{Fe}(\mathrm{II})$-catalysed transformation and reactivity of $\mathrm{Fe}(\mathrm{III})$ minerals. Geochim. Cosmochim. Acta 73, 4409-4422.

Kakol Z., Honig J.M. (1989) Influence of deviations from ideal stoichiometry on the anisotropy parameters of magnetite $\mathrm{Fe}_{3(1-\S} \mathrm{O}_{4}$, Phys. Rev. B, 40, 9090-9097.

Kappler A., Schink B. and Newman D. K. (2005) Fe(III) mineral formation and cell encrustation by the nitrate-dependent Fe(II)-oxidizer strain BoFeN1. Geobiology 3, 235-245.

Kaznatcheev K. V., Karunakaran C., Lanke U. D., Urquhart S. G., Obst M. and Hitchcock A. P. (2007) Soft X-ray spectromicroscopy beamline at the CLS: Commissioning results. Nucl. Instruments Methods Phys. Res. Sect. Accel. Spectrometers Detect. Assoc. Equip. 582, 96-99.

Klein C. (2005) Some Precambrian banded iron-formations (BIFs) from around the world: Their age, geologic setting, mineralogy, metamorphism, geochemistry, and origins. Am. Miner. 90, 1473-1499.

Klueglein N. and Kappler A. (2013) Abiotic oxidation of Fe(II) by reactive nitrogen species in cultures of the nitrate-reducing Fe(II) oxidizer Acidovorax sp. BoFeN1 questioning the existence of enzymatic Fe(II) oxidation. Geobiology 11, 180-190.

Köhler I., Konhauser K. O., Papineau D., Bekker A. and Kappler A. (2013) Biological carbon precursor to diagenetic siderite with spherical structures in iron formations. Nat. Commun. 4, 1741.

Komeili A. (2012) Molecular mechanisms of compartmentalization and biomineralization in magnetotactic bacteria. Fems Microbiol. Rev. 36, 232-255.

Konhauser K. O., Hamade T., Raiswell R., Morris R. C., Grant Ferris F., Southam G. and Canfield D. E. (2002) Could bacteria have formed the Precambrian banded iron formations? Geology 30, 1079. 
Konhauser K. O., Lalonde S. V., Planavsky N. J., Pecoits E., Lyons T. W., Mojzsis S. J., Rouxel O. J., Barley M. E., Rosìere C., Fralick P. W., Kump L. R. and Bekker A. (2011) Aerobic bacterial pyrite oxidation and acid rock drainage during the Great Oxidation Event. Nature 478, 369-373.

Konhauser K. O., Pecoits E., Lalonde S. V., Papineau D., Nisbet E. G., Barley M. E., Arndt N. T., Zahnle K. and Kamber B. S. (2009) Oceanic nickel depletion and a methanogen famine before the Great Oxidation Event. Nature 458, 750-753.

Kopf S. H., Henny C. and Newman D. K. (2013) Ligand-Enhanced Abiotic Iron Oxidation and the Effects of Chemical versus Biological Iron Cycling in Anoxic Environments. Environ. Sci. Technol. 47, 2602-2611.

Kukkadapu R.K., Zachara J.M., Frederickson J.K., Kennedy D.W., Dohnalkova A.C., McCready D.E. (2005) Ferrous hydroxy carbonate is a stable transformation product of biogenic magnetite. Am. Min. 90, 510-515.

Kump L. R. (2008) The rise of atmospheric oxygen. Nature 451, 277-278.

Larese-Casanova P., Haderlein S. B. and Kappler A. (2010) Biomineralization of lepidocrocite and goethite by nitrate-reducing $\mathrm{Fe}(\mathrm{II})$-oxidizing bacteria: Effect of $\mathrm{pH}$, bicarbonate, phosphate, and humic acids. Geochim. Cosmochim. Acta 74, 3721-3734.

Li J. H., Pan Y. X., Chen G. J., Liu Q. S., Tian L. X., Lin W. (2009) Magnetite magnetosome and fragmental chain formation of Magnetospirillum magneticum AMB-1: Transmission electron microscopy observations. Geophys. J. Int., 177, 33-42.

Li J. H., Pan Y., Liu Q., Yu-Zhang K., Menguy N., Che R., Qin H., Lin W., Wu W., Petersen N. and Yang X. (2010) Biomineralization, crystallography and magnetic properties of bullet-shaped magnetite magnetosomes in giant rod magnetotactic bacteria. Earth Planet. Sci. Lett. 293, 368-376.

Li J.H., Wu W.F., Liu Q.S., Pan Y.X. (2012) Magnetic anisotropy, magnetostatic interactions and identification of magnetofossils. Geochem. Geophys. Geosyst. 13, doi.10.1029/2012GC004384

Li J. H., Benzerara K., Bernard S., Beyssac O. (2013a) The link between biomineralization and fossilization of bacteria: insights from field and experimental studies. Chem. Geol. 359, 49-69.

Li J. H., Ge K., Pan Y., Williams W., Liu Q., Qin H. (2013b) A strong angular dependence of magnetic properties of magnetosome chains: Implications for rock magnetism and paleomagnetism. Geochem., Geophys., Geosyst., 14, 3887-3907.

Li Y., Katzmann E., Borg S. and Schuler D. (2012) The Periplasmic Nitrate Reductase Nap Is Required for Anaerobic Growth and Involved in Redox Control of Magnetite Biomineralization in Magnetospirillum gryphiswaldense. J. Bacteriol. 194, 48474856. 
Li Y.-L., Konhauser K. O., Cole D. R. and Phelps T. J. (2011) Mineral ecophysiological data provide growing evidence for microbial activity in banded-iron formations. Geology 39, 707-710.

Li Y.L. (2012) Hexagonal platelet-like magnetite as a biosignature of thermophilic ironreducing bacteria and its applications to the exploration of the modern deep, hot biosphere and the emergence of iron-reducing bacteria in early precambrian oceans. Astrobiology, 12(2), 1100-1108.

Li Y.-L., Konhauser K. O., Kappler A. and Hao X.-L. (2013) Experimental low-grade alteration of biogenic magnetite indicates microbial involvement in generation of banded iron formations. Earth Planet. Sci. Lett. 361, 229-237.

Lovley D.R., Stolz J.F., Nord G.L., Phillips E.J.P. (1987) Anaerobic production of magnetite by a dissimilatory iron-reducing microorganism. Nature, 330, 252-254.

McCammon (1995) Mossbauer spectroscopy of minerals. In: Ahrens T.J. (ed) Mineral physics and crystallography: a handbook of physical constants. AGU ref. Shelf 2, 332-347.

Miot J., Benzerara K., Morin G., Kappler A., Bernard S., Obst M., Férard C., Skouri-Panet F., Guigner J.-M., Posth N., Galvez M., Brown G. E. and Guyot F. (2009a) Iron biomineralization by anaerobic neutrophilic iron-oxidizing bacteria. Geochim. Cosmochim. Acta 73, 696-711.

Miot J., Benzerara K., Morin G., Bernard S., Beyssac O., Larquet E., Kappler A. and Guyot F. (2009b) Transformation of vivianite by anaerobic nitrate-reducing iron-oxidizing bacteria. Geobiology 7, 373-384.

Miot J., Benzerara K., Obst M., Kappler A., Hegler F., Schadler S., Bouchez C., Guyot F. and Morin G. (2009c) Extracellular Iron Biomineralization by Photoautotrophic IronOxidizing Bacteria. Appl. Environ. Microbiol. 75, 5586-5591.

Miot J., Maclellan K., Benzerara K. and Boisset N. (2011) Preservation of protein globules and peptidoglycan in the mineralized cell wall of nitrate-reducing, iron(II)-oxidizing bacteria: a cryo-electron microscopy study. Geobiology 9, 459-470.

Miot J., Recham N., Larcher D., Guyot F., Brest J., Tarascon J.M. (2014) Biomineralized $\alpha$ $\mathrm{Fe}_{2} \mathrm{O}_{3}$ : texture and electrochemical reaction with Li. Energy \& Environ. Sci. 7, 451-460.

Misawa T., Hashimoto K., Shimodarai S. (1974) The mechanism of formation of iron oxide and oxyhydroxides in aqueous solutions at room temperature. Corros. Sci. 14, 131-149.

Mitov I., Paneva D. and Kunev B. (2002) Comparative study of the thermal decomposition of iron oxyhydroxides. Thermochim. Acta 386, 179-188.

Morin G., Calas G. (2006) Arsenic in soils, mine tailings and former industrial sites. Elements 2, 97-101.

Morin G., Wang Y.H., Ona-Nguema G., Juillot F., Calas G., Menguy N., Aubry E., Bargar J.R., Brown G.E. (2009) EXAFS and HRTEM evidence for As(III)-containing surface 
precipitates on nanocrystalline magnetite: implications for As sequestration. Lngmuir, 25(16), 9119-9128.

Morris R. C. (1993) Genetic modelling for banded iron-formation of the Hamersley Group, Pilbara Craton, Western Australia. Precambrian Res. 60, 243-286.

Moskowitz B.M., Frankel R.B., Bazylinski D.A. (1993) Rock magnetic criteria for the detection of biogenic magnetite. Earth. Planet. Sci. Lett. 120, 283-300.

Muxworthy A.R., McClelland E. (2000) Review of the low-temperature magnetic properties of magnetite from a rock magnetic perspective. Geophys. J. Int. 140, 101-114.

Muxworthy A., Heslop D. and Williams W. (2004) Influence of magnetostatic interactions on first-order-reversal-curve (FORC) diagrams: a micromagnetic approach: FORC diagrams and interactions. Geophys. J. Int. 158, 888-897.

Muxworthy A.R., Williams W. (2009) Critical superparmagnetic/single-domain grain sizes in interacting magnetite particles: implications for magnetosome crystals. J. R. Soc. Interface, 6 , 1207-1212.

Ona-Nguema G., Abdelmoula M., Jorand F., Benali O., Block J.-C. and Génin J.-M. R. (2002) Iron(II,III) Hydroxycarbonate Green Rust Formation and Stabilization from Lepidocrocite Bioreduction. Environ. Sci. Technol. 36, 16-20.

Pan Y., Petersen N., Winklhofer M., Davila A. F., Liu Q., Frederichs T., Hanzlik M. and Zhu R. (2005) Rock magnetic properties of uncultured magnetotactic bacteria. Earth Planet. Sci. Lett. 237, 311-325.

Pantke C., Obst M., Benzerara K., Morin G., Ona-Nguema G., Dippon U. and Kappler A. (2012) Green Rust Formation during Fe(II) Oxidation by the Nitrate-Reducing Acidovorax sp. Strain BoFeN1. Environ. Sci. Technol. 46, 1439-1446.

Papineau D., De Gregorio B. T., Stroud R. M., Steele A., Pecoits E., Konhauser K., Wang J. and Fogel M. L. (2010) Ancient graphite in the Eoarchean quartz-pyroxene rocks from Akilia in southern West Greenland II: Isotopic and chemical compositions and comparison with Paleoproterozoic banded iron formations. Geochim. Cosmochim. Acta 74, 5884-5905.

Pecoits E., Gingras M. K., Barley M. E., Kappler A., Posth N. R. and Konhauser K. O. (2009) Petrography and geochemistry of the Dales Gorge banded iron formation: Paragenetic sequence, source and implications for palaeo-ocean chemistry. Precambrian Res. 172, $163-187$.

Petersen N., von Dobeneck T. and Vali H. (1986) Fossil bacterial magnetite in deep-sea sediments from the South Atlantic Ocean. Nature 320, 611-615.

Pike C.R., Roberts A.P, Verosub K.L. (1999) Characterizing interactions in fine magnetic particle systems using first order reversal curves. J. Appl. Phys. 85, 6660-6667. 
Planavsky N., Rouxel O., Bekker A., Shapiro R., Fralick P. and Knudsen A. (2009) Ironoxidizing microbial ecosystems thrived in late Paleoproterozoic redox-stratified oceans. Earth Planet. Sci. Lett. 286, 230-242.

Posth N. R., Hegler F., Konhauser K. O. and Kappler A. (2008) Alternating Si and Fe deposition caused by temperature fluctuations in Precambrian oceans. Nat. Geosci. 1, 703-708.

Posth N. R., Kohler I., Swanner E. D., Schroder C., Wellmann E., Binder B., Konhauser K. O., Neumann U., Berthold C., Nowak M., Kappler A. (2013) Simulating Precambrian banded iron formation diagenesis. Chem. Geol. 362, 66-73.

Rasmussen B., Fletcher I. R., Brocks J. J. and Kilburn M. R. (2008) Reassessing the first appearance of eukaryotes and cyanobacteria. Nature 455, 1101-1104.

Refait P., Abdelmoula M. and GÉnin J.-M. R. (1998) Mechanisms of formation and structure of green rust one in aqueous corrosion of iron in the presence of chloride ions. Corros. Sci. 40, 1547-1560.

Roberts A. P., Pike C. R. and Verosub K. L. (2000) First-order reversal curve diagrams: A new tool for characterizing the magnetic properties of natural samples. J. Geophys. Res. 105, 28461.

Roberts A.P., Florindo F., Villa G., Chang L., Jovane L., Bohaty S.M., Larrasoana J.C., Heslop D., Fitz Gerald J.D. (2011) Magnetotactic bacterial abundance in pelagic marine environments is limited by organic carbon flux and availability of dissolved iron. Earth Planet. Sc. Lett. 310(3-4), 441-452.

Roberts A. P., Chang L., Heslop D., Florindo F., Larrasoana J. C. (2012) Searching for singledomain magnetite in the "pseudo-single-domain" sedimentary haystack: Implications of biogenic magnetite preservation for sediment magnetism and relative paleointensity determinations. J. Geophys. Res. 117, B8104, doi:8110.1029/2012JB009412.

Ruby C., Abdelmoula M., Naille S., Renard A., Khare V., Ona-Nguema G., Morin G. and Génin J.-M. R. (2010) Oxidation modes and thermodynamics of FeII-III oxyhydroxycarbonate green rust: Dissolution-precipitation versus in situ deprotonation. Geochim. Cosmochim. Acta 74, 953-966.

Schädler S., Burkhardt C., Hegler F., Straub K. L., Miot J., Benzerara K. and Kappler A. (2009) Formation of Cell-Iron-Mineral Aggregates by Phototrophic and NitrateReducing Anaerobic Fe(II)-Oxidizing Bacteria. Geomicrobiol. J. 26, 93-103.

Scott C. T., Bekker A., Reinhard C. T., Schnetger B., Krapez B., Rumble D. and Lyons T. W. (2011) Late Archean euxinic conditions before the rise of atmospheric oxygen. Geology 39, 119-122.

Usman M., Abdelmoula M., Hanna K., Grégoire B., Faure P. and Ruby C. (2012) FeII induced mineralogical transformations of ferric oxyhydroxides into magnetite of variable stoichiometry and morphology. J. Solid State Chem. 194, 328-335. 
Vali H. (2004) Formation of tabular single-domain magnetite induced by Geobacter metallireducens GS-15. Proc. Natl. Acad. Sci. 101, 16121-16126.

3 Vandenberghe R.E., Barrero C.A., da Costa G.M., Van San E., De GRave E. (2000)

4 Mossbauer characterization of iron oxides and (oxy)hydroxides; the present state of the art.

5 Hyper. Interact. 126, 247-259.

6

Viollier E., Inglett P. ., Hunter K., Roychoudhury A. . and Van Cappellen P. (2000) The ferrozine method revisited: $\mathrm{Fe}(\mathrm{II}) / \mathrm{Fe}(\mathrm{III})$ determination in natural waters. Appl. Geochem. 15, 785-790.

Wang R., Lovlie R. (2008) SP-grain production during thermal demagnetization of some Chinese loess/palaeosol. Geophys. J. Int. 172, 504-512.

Wang Y., Morin G., Ona-Nguema G., Juillot F., Calas G. and Brown G. E. (2011) Distinctive Arsenic(V) Trapping Modes by Magnetite Nanoparticles Induced by Different Sorption Processes. Environ. Sci. Technol. 45, 7258-7266.

Yamazaki T. and Shimono T. (2013) Abundant bacterial magnetite occurrence in oxic red clay. Geology, doi: 10.1130/G34782.1.

Zhang C.L., Vali H., Romanek C.S., Phelps T.J., Liu S.V. (1998) Formation of single-domain magnetite by a thermophilic bacterium. Am. Mineral., 83 (11-12), 1409-1418.

Zegeye A., Bonneville S., Benning L. G., Sturm A., Fowle D. A., Jones C., Canfield D. E., Ruby C., MacLean L. C., Nomosatryo S., Crowe S. A. and Poulton S. W. (2012) Green rust formation controls nutrient availability in a ferruginous water column. Geology 40, 599-602. 
Figure 1 - X-ray diffraction patterns of solid phases produced in abiotic control and BoFeN1 cultures.

Figure 2 - Room-temperature Mössbauer spectra of the 4-day old precipitate collected from BoFeN1 cultures (A) and the 4-month old abiotic control (B). Dots: experimental curves; line: global computed curve; coloured lines: elementary components.

Figure 3 - TEM analysis of the mineralogy obtained in cultures of BoFeN1 at $\mathrm{pH} 7.6$ (A to $\mathrm{L}$ ) and in abiotic control ( $\mathrm{M}$ to $\mathrm{O}$ ). (A) After $15 \mathrm{~h}$, bacteria are encrusted with lepidocrocite, as shown by SAED (bottom), whereas green rust is observed in the extracellular medium (corresponding SAED pattern displayed in the top panel). (B) 15-h old sample, showing local transformation of GR to needles. (C) 38-h old sample: magnetite particles at the surface of partly transformed GR (with corresponding SAED pattern). (D) 38-h old sample: magnetite particles (white) at the surface of a GR hexagonal platelet (light grey) observed by STEM. (E) 2-day old sample: extracellular magnetite with corresponding SAED pattern. (F) 15-day old sample observed in thin section showing lepidocrocite precipitated within the periplasm. $(\mathrm{G}$ and H) HRTEM analysis of these lepidocrocite particles showing crystallographic orientation with the (020) axis parallel to the cell wall direction. (I) to (L): HRTEM observations of 4month old BoFeN1 sample, with preserved crystallographic orientation of lepidocrocite within the periplasm (I) and extracellular single domain magnetite crystals (J, K, L). (M) to (O): (HR)TEM observations of single domain magnetite crystals produced in the abiotic control after 4 months. Arrow in (O) indicates an amorphous rim at the surface of the Mt particle.

Figure 4 - Distribution of grain size of magnetite particles in 15-day old (A) and 4-month old BoFeN1 cultures (B) and in the 4-month old abiotic control (C).

Figure 5 - SEM observations of magnetite formed in 4-month old cultures of BoFeN1 (A, B) and in 4-month old abiotic control (C, D).

Figure 6 - STXM analysis at the Fe $\mathrm{L}_{2,3}$-edges of BoFeN1 cultures (A to $\mathrm{G}$ ) and abiotic control (H to K). (A, B, C): 3-h old BoFeN1 culture, with the map of the GR (A) and oxidized GR (B) respectively as well as the composite overlay map (C). (D, E, F): 15-day old BoFeN1 sample with the maps of magnetite (D) and lepidocrocite (E) and the corresponding overlap (F). (G) NEXAFS spectra collected on starting GR (green), on the bacterium in (C) (orange), on a bacterium from a 1-day old sample (red) and on extracellular magnetite in (F) (black). The NEXAFS spectrum of the 3-h old bacteria was fitted with $83 \%$ of the GR component and $17 \%$ of the lepidocrocite component. $(\mathrm{H}, \mathrm{I}, \mathrm{J})$ : 4-month old abiotic control, with GR-like $(\mathrm{H})$ and magnetite-like (I) maps and corresponding overlap (J). (K) displays the corresponding NEXAFS spectra. 
Figure 7 - STXM analysis of BoFeN1 1-day old sample at the C K-edge and $\mathrm{Fe} \mathrm{L}_{2,3}$-edges. (A): map of organic carbon, mainly showing the contribution of proteins $(288.2-280 \mathrm{eV})$. (B): map of total Fe $(710-700 \mathrm{eV})$. (C): Composite map of proteins $(\mathrm{C}, 288.2-280 \mathrm{eV}$, blue), lepidocrocite ( $\mathrm{Lp}, 710 \mathrm{eV}-708.5 \mathrm{eV}$, pink) and $\mathrm{Fe}(\mathrm{II})$-bearing phase, i.e. magnetite (Mt, $708.5-700 \mathrm{eV}$, green). (D) C K-edge NEXAFS spectra of reference albumin and mineralized 1-day old BoFeN1 cells. Scale bars, $1 \mu \mathrm{m}$.

Figure 8 - Magnetic properties of green rust transformed by BoFeN1: FORC diagrams for BoFeN1 cultures after $3 \mathrm{~h}$ (A) and 4 days (B), thermal demagnetization curves of SIRM10K_2.5T for 4-day old BoFeN1 (C), and FORC diagram obtained for the 4-month old abiotic control (D).

Figure 9 - Proposed mechanisms for the transformation of GR to periplasmic lepidocrocite and extracellular magnetite.

\section{Table captions}

Table 1 - Mössbauer hyperfine parameters of spectra from Fig. 2 measured at room temperature.

\begin{tabular}{|c|c|c|c|c|c|}
\hline & $\delta(\mathbf{m m} / \mathbf{s})$ & $\Delta$ or $\mathcal{E}(\mathrm{mm} / \mathrm{s})$ & $H F(\mathrm{~T})$ & $R A(\%)$ & Attribution \\
\hline \multicolumn{6}{|c|}{ 4-day old BoFeN1 culture } \\
\hline$S_{\mathrm{A}}$ & $0.30 \pm 0.01$ & $-0.02 \pm 0.01$ & $48.7 \pm 0.1$ & $39 \pm 1$ & Magnetite (Td) \\
\hline$S_{\mathrm{B}}$ & $0.63 \pm 0.01$ & $0.02 \pm 0.01$ & $45.4 \pm 0.1$ & $51 \pm 1$ & Magnetite (Oh) \\
\hline$D_{1}$ & $\mathbf{0 . 3 7} \pm \mathbf{0 . 0 1}$ & $0.61 \pm 0.02$ & & $10 \pm 1$ & Lepidocrocite \\
\hline \multicolumn{6}{|c|}{ 4-month old abiotic control } \\
\hline$S_{\mathrm{A}}$ & $0.29 \pm 0.01$ & $-0.02 \pm 0.02$ & $48.7 \pm 0.1$ & $34 \pm 3$ & Magnetite (Td) \\
\hline$S_{\mathrm{B}}$ & $0.64 \pm 0.02$ & $0.02 \pm 0.03$ & $45.4 \pm 0.1$ & $58 \pm 4$ & Magnetite (Oh) \\
\hline $\boldsymbol{D}_{\gamma}$ & $0.18 \pm 0.08$ & $0.66 \pm 0.12$ & & $8 \pm 7$ & $\begin{array}{l}\mathrm{Fe}(\mathrm{III}) \text { in XRD- } \\
\text { amorphous Fe } \\
\text { oxide }\end{array}$ \\
\hline
\end{tabular}
relative abundance. 


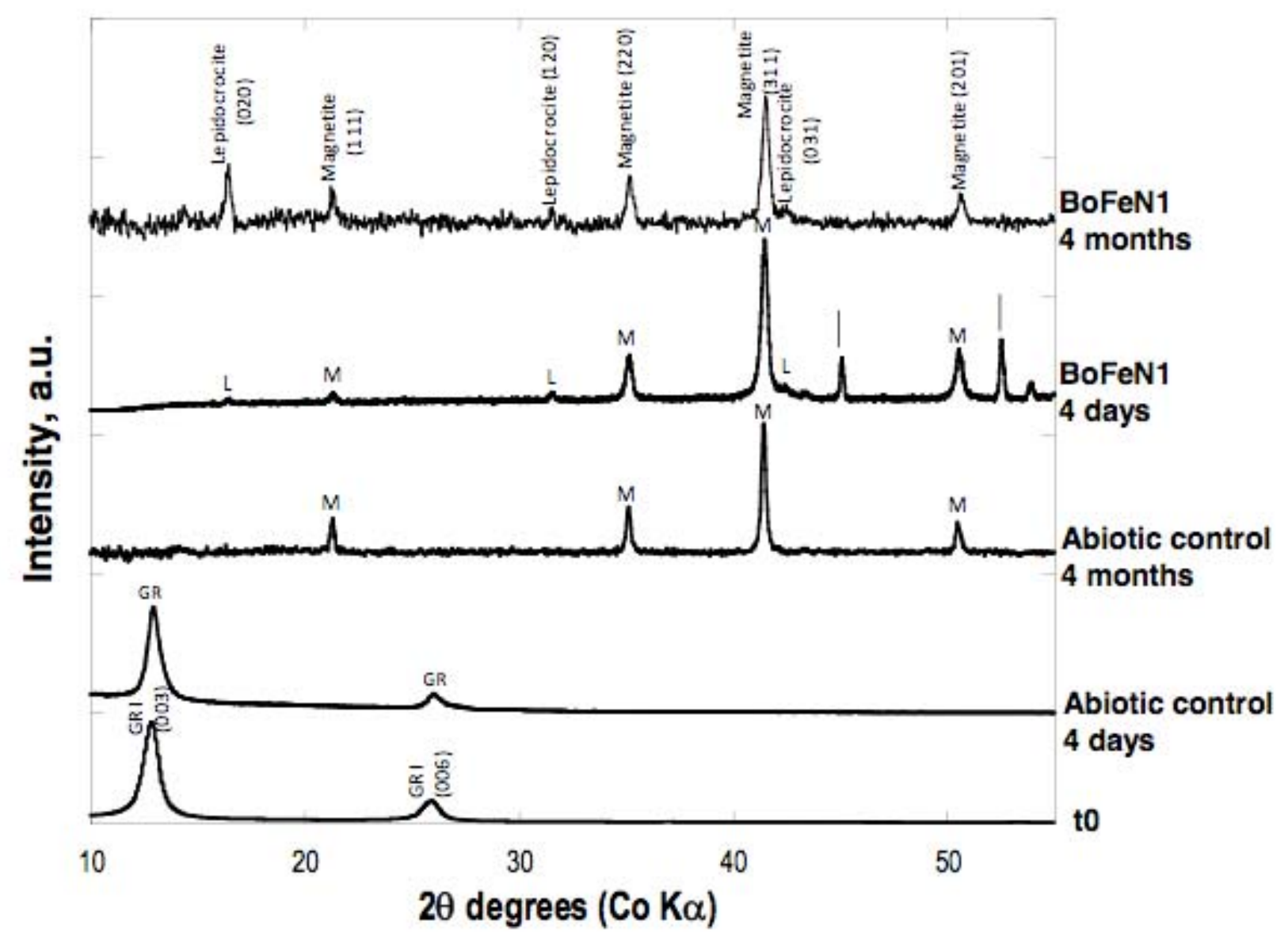

Figure 1 

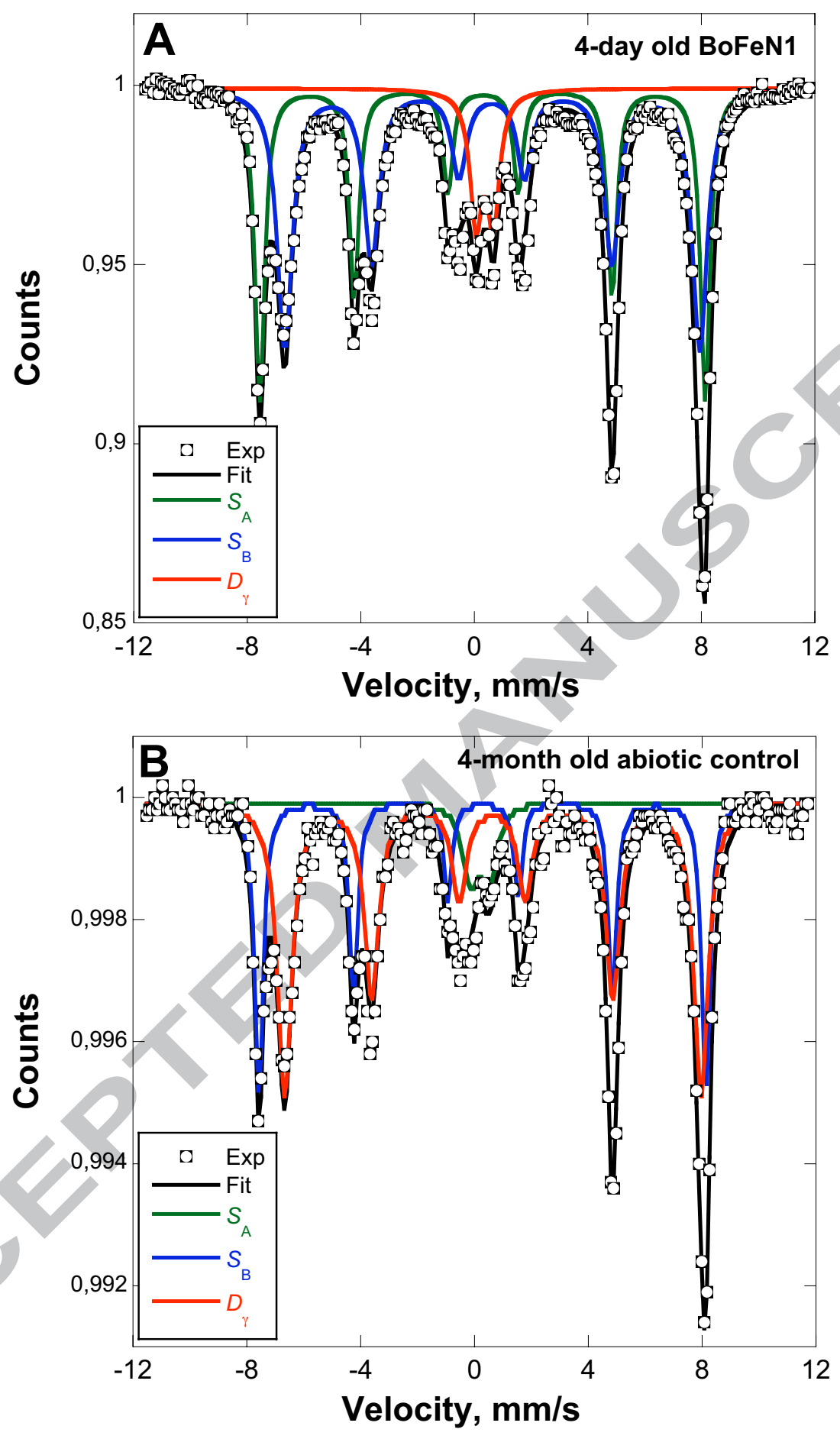

Figure 2 

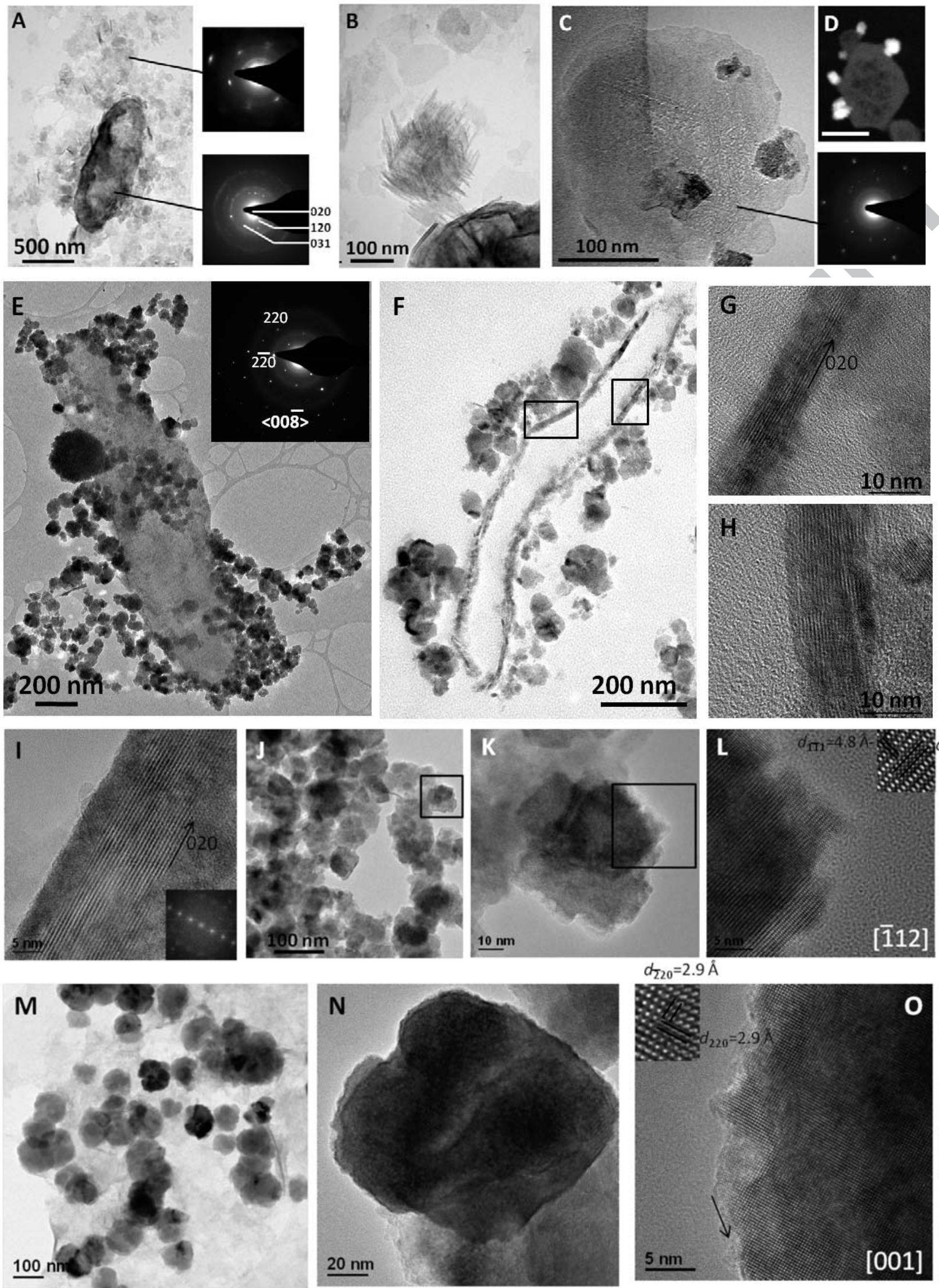

Figure 3 

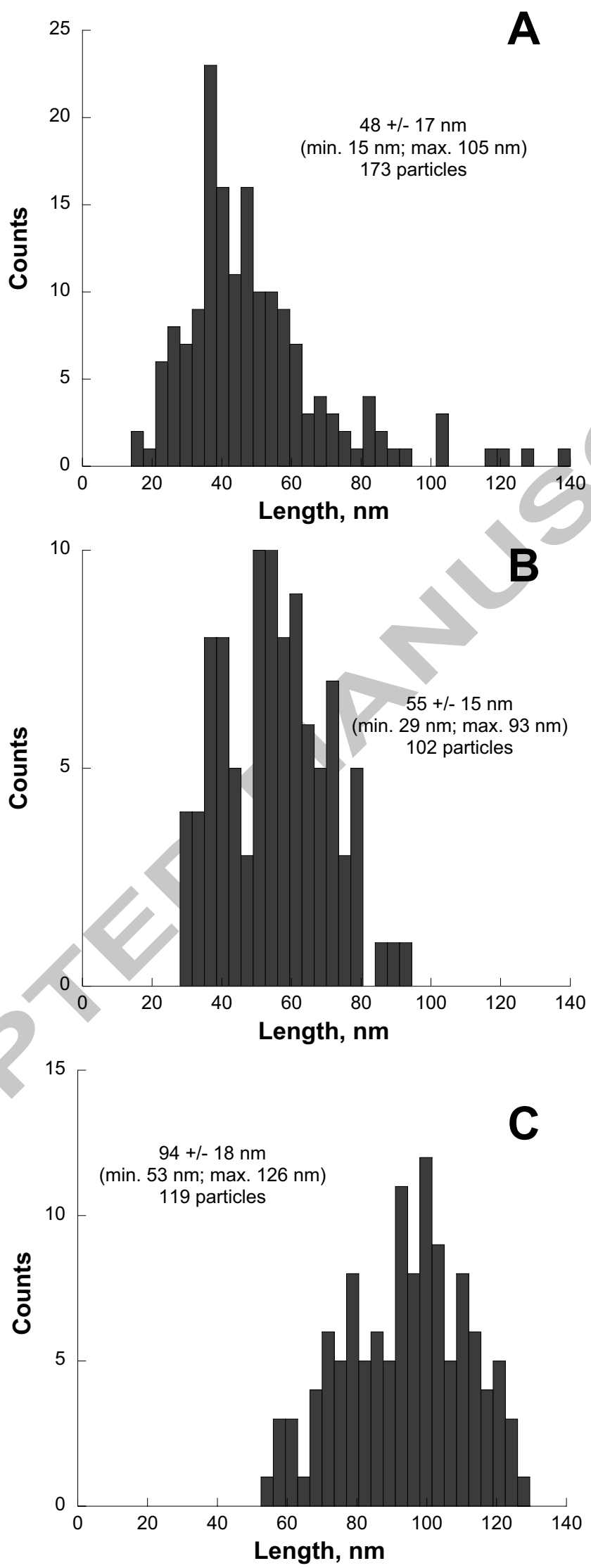

Figure 4 

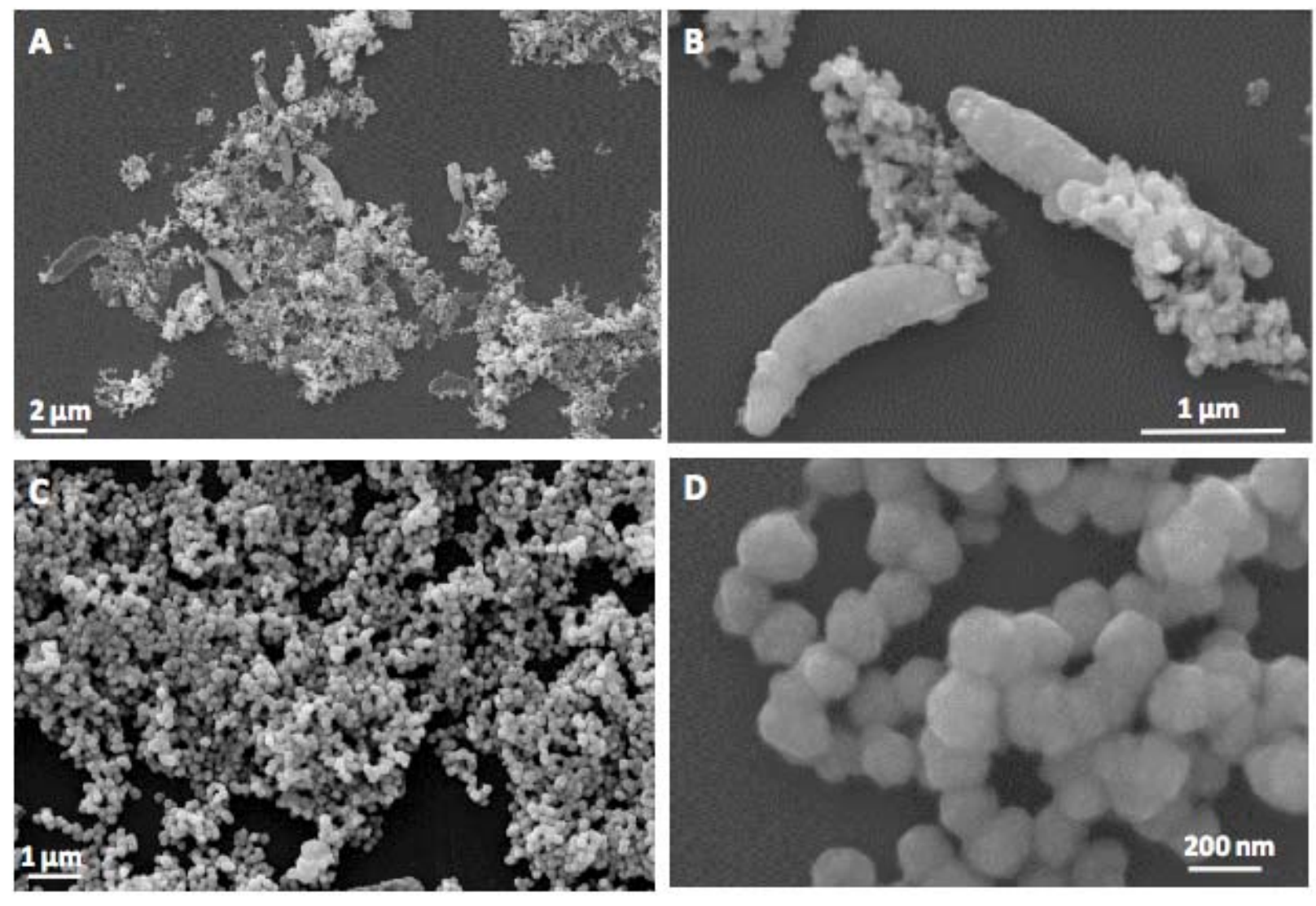

Figure 5 

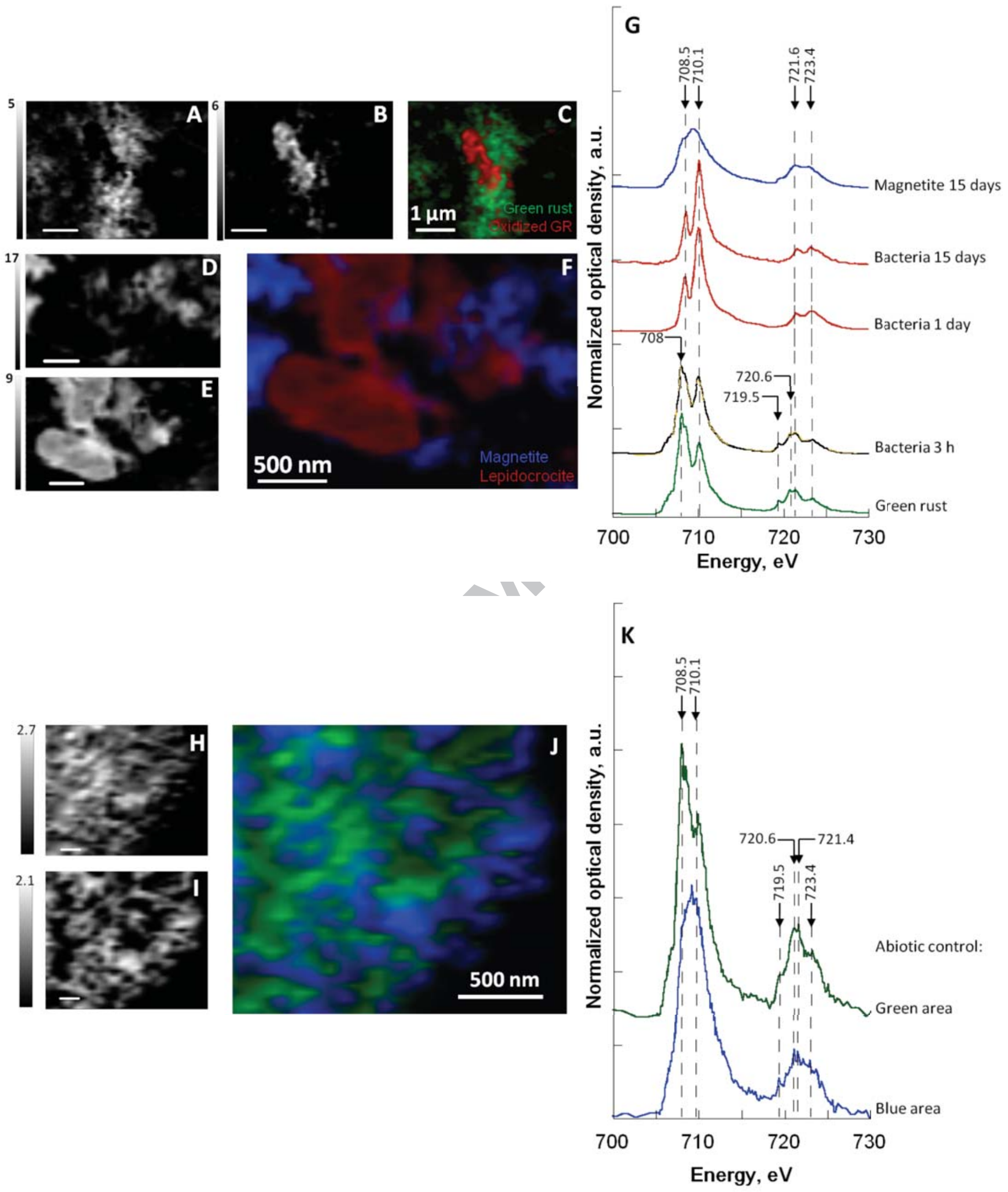

Figure 6 

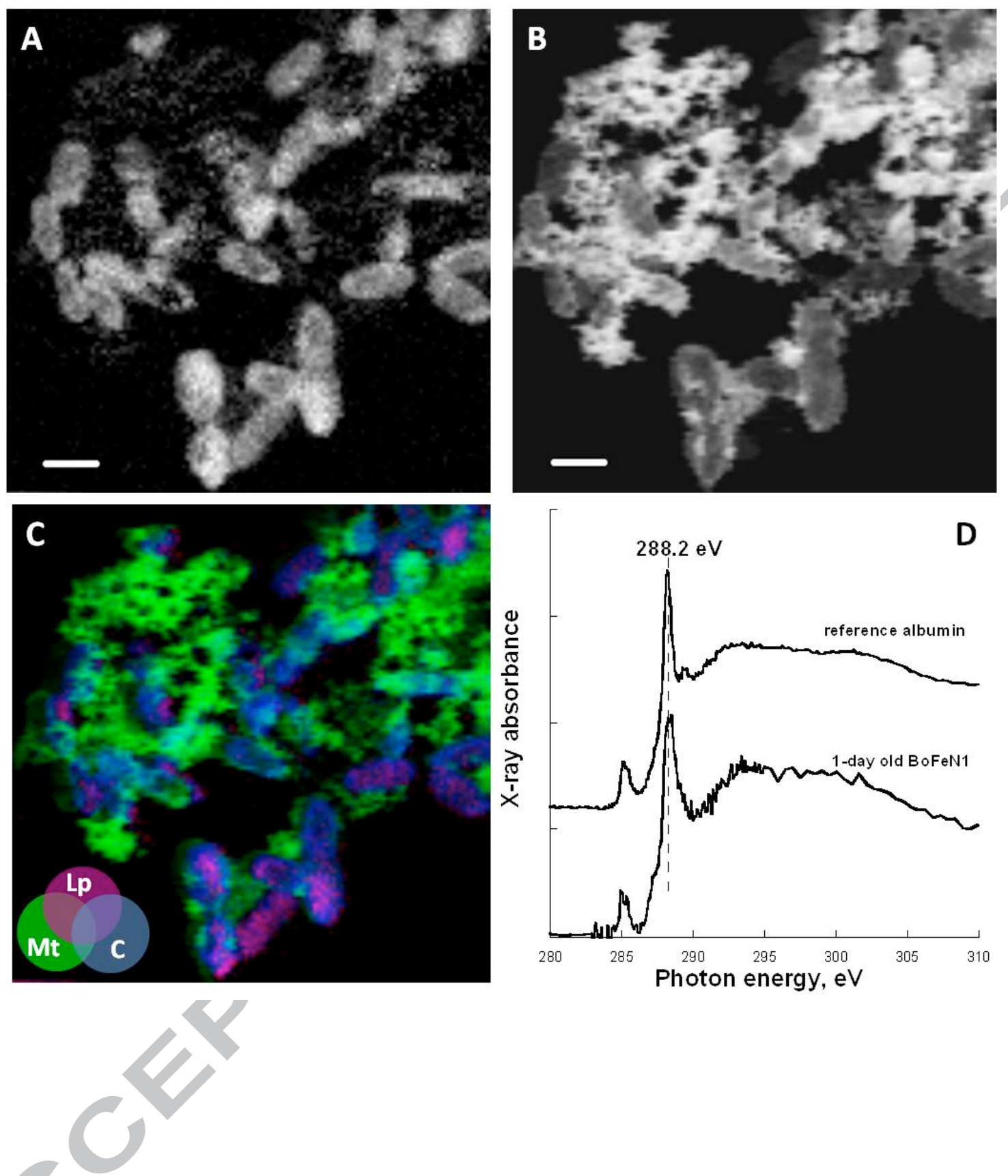

Figure 7 

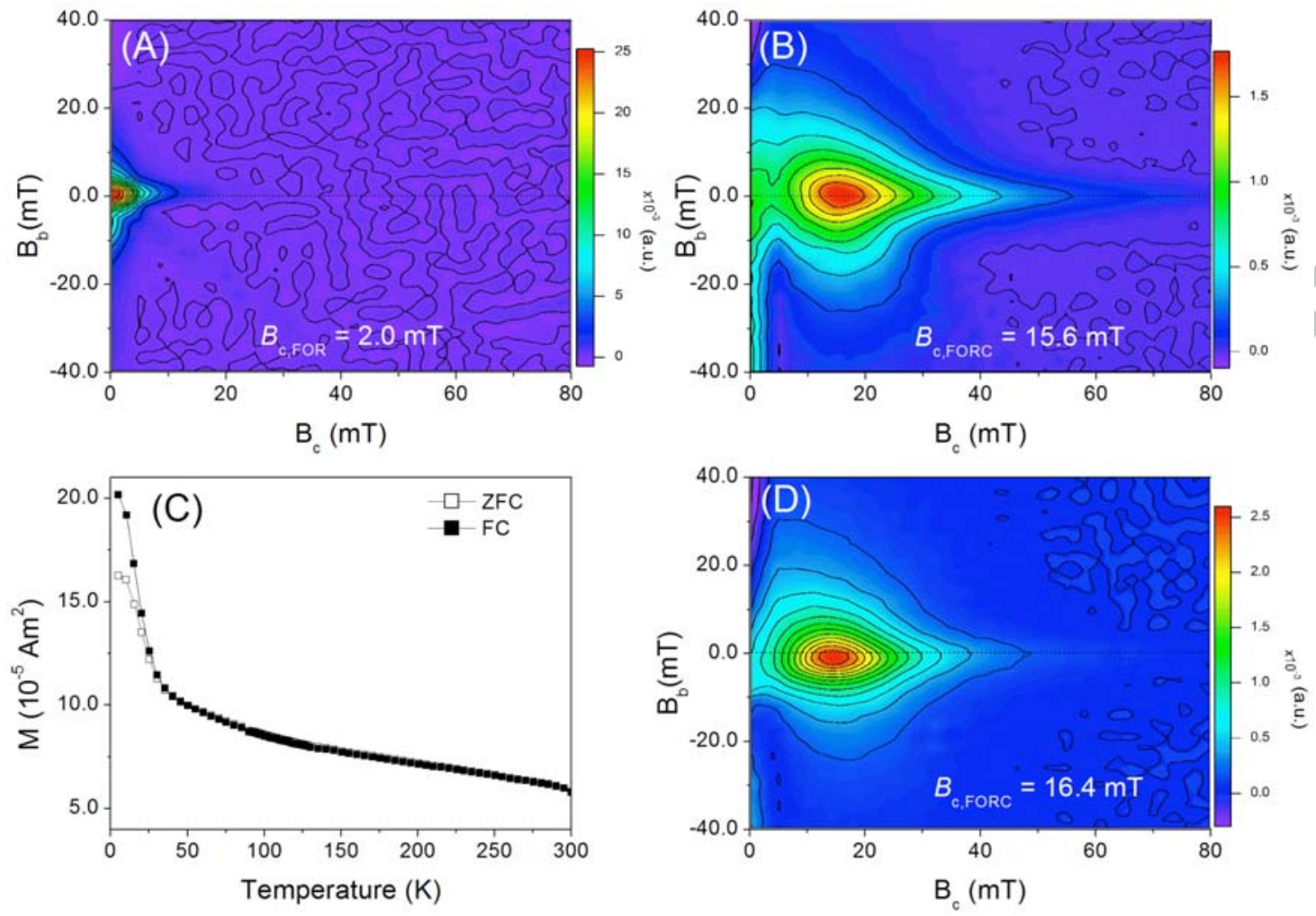

Figure 8 


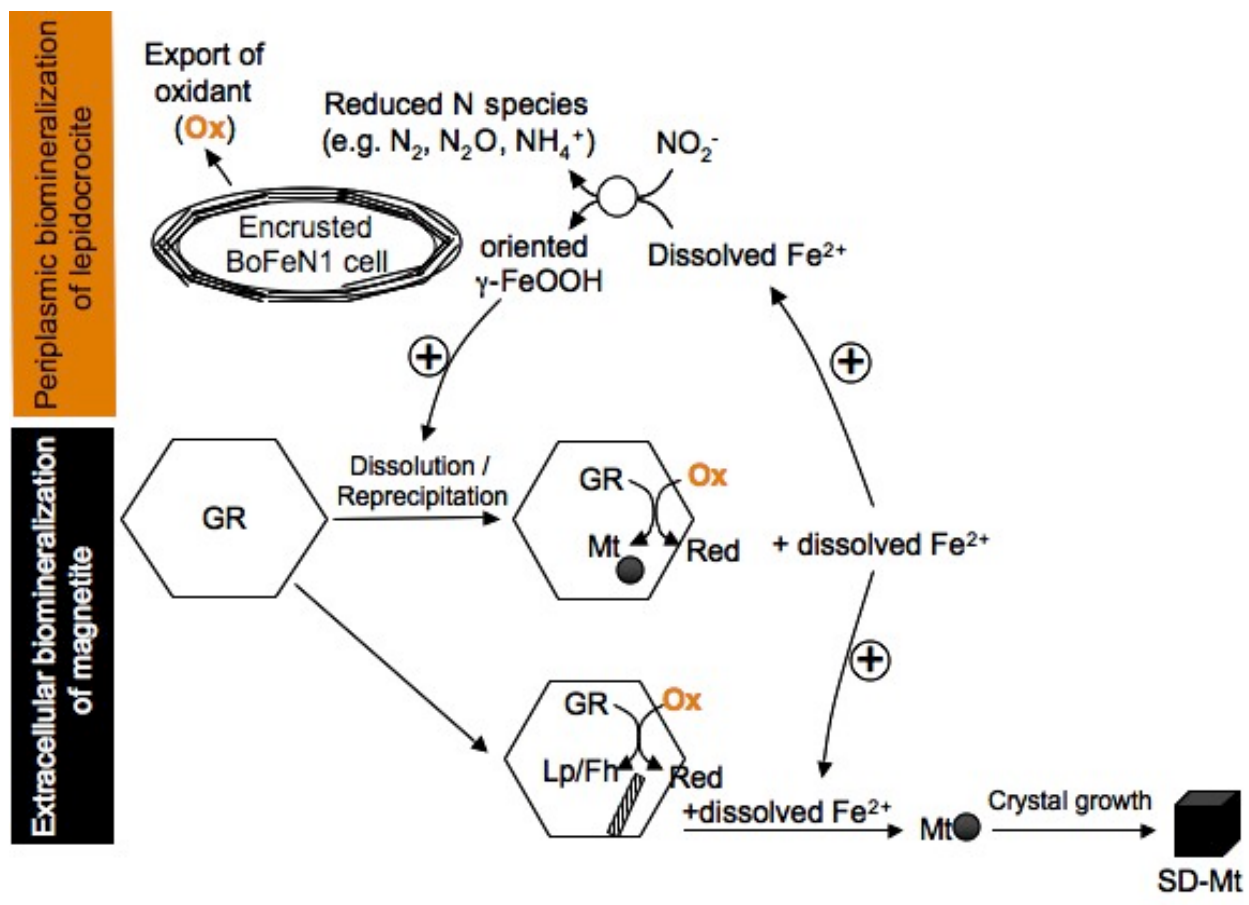

Figure 9 


\begin{tabular}{|c|c|c|c|c|c|}
\hline & $\delta(\mathrm{mm} / \mathrm{s})$ & $\Delta$ or $\varepsilon(\mathrm{mm} / \mathrm{s})$ & $H F(\mathrm{~T})$ & $R A(\%)$ & Attribution \\
\hline \multicolumn{6}{|c|}{ 4-day old BoFeN1 culture } \\
\hline$S_{\mathrm{A}}$ & $0.30 \pm 0.01$ & $-0.02 \pm 0.01$ & $48.7 \pm 0.1$ & $39 \pm 1$ & Magnetite (Td) \\
\hline$S_{\mathrm{B}}$ & $0.63 \pm 0.01$ & $0.02 \pm 0.01$ & $45.4 \pm 0.1$ & $51 \pm 1$ & Magnetite (Oh) \\
\hline $\boldsymbol{D}_{\gamma}$ & $\mathbf{0 . 3 7} \pm \mathbf{0 . 0 1}$ & $0.61 \pm 0.02$ & & $10 \pm 1$ & Lepidocrocite \\
\hline \multicolumn{6}{|c|}{ 4-month old abiotic control } \\
\hline$S_{\mathrm{A}}$ & $0.29 \pm 0.01$ & $-0.02 \pm 0.02$ & $48.7 \pm 0.1$ & $34 \pm 3$ & Magnetite (Td) \\
\hline$S_{\mathrm{B}}$ & $0.64 \pm 0.02$ & $0.02 \pm 0.03$ & $45.4 \pm 0.1$ & $58 \pm 4$ & Magnetite (Oh) \\
\hline $\boldsymbol{D}_{\gamma}$ & $0.18 \pm 0.08$ & $0.66 \pm 0.12$ & & $8 \pm 7$ & $\begin{array}{l}\mathrm{Fe}(\mathrm{III}) \text { in XRD- } \\
\text { amorphous } \mathrm{Fe}^{\mathrm{III}} \\
\text { oxide }\end{array}$ \\
\hline
\end{tabular}

$\delta$, isomer shift taking $\alpha$-iron as reference at room temperature; $\Delta$ or $\varepsilon$, quadrupole splitting; $R A$, relative abundance.

\section{Table 1}

